\title{
O Olimpismo hoje. De uma diplomacia do silêncio para uma diplomacia silenciosa. 0 caso das duas Chinas
}

\author{
Gustavo Pires
}

\section{RESUMO}

O Movimento Olímpico, devido à contestação política que têm como cenário de fundo os Jogos de Pequim (2008), vive um momento crucial que, por paradoxal que possa parecer, está a propiciar as condições necessárias à sua evolução e ao seu progresso. Por um lado, a República Popular da China (RPC) comprometeu-se a realizar a abertura necessária no âmbito do respeito pelos Direitos Humanos quando, em 2001, Pequim recebeu a incumbência de organizar os Jogos da XXIX Olimpíada. Por outro lado, o Comité Olímpico Internacional (COI) passou a sofrer as maiores pressões das mais diversas organizações não governamentais (ONGs), a fim de obrigar a China a cumprir o prometido. Tal como Jacques Rogge reconheceu, o Movimento Olímpico acabou por ficar no meio de uma crise difícil de gerir a contento de todos. Contudo, o ambiente de crises entre o COI e a RPC não era uma situação totalmente desconhecida para as duas entidades. De facto, no início dos anos cinquenta desencadeou-se o designado problema das "duas Chinas" que chegou ao ponto do Comité Olímpico Nacional (CON) da RPC, em plena guerrafria, abandonar o COI e a generalidade das federações internacionais (FI). Ao tempo, Avery Brundage Presidente do COI, afirmava que o desporto nada tinha a ver com a política. Passados mais de cinquenta anos, como se tem vindo a constatar na Olimpíada de Pequim, a questão das relações entre o desporto e a política, pelas mais diversas razões, ainda não está resolvida. Por um lado, os dirigentes políticos continuam a manipular as questões desportivas de acordo com as suas conveniências, por outro lado, contra todas as evidências, a generalidade dos dirigentes do mundo do Movimento Olímpico continua a afirmar que o desporto nada tem a ver com a política. O objectivo do presente ensaio é analisar a questão política do desporto tendo em consideração as relações passadas e presentes entre a RPC e COI, no quadro do problema das "duas Chinas".

Palavras-chave: China, desenvolvimento, ideologia, Olimpismo, política

\author{
Faculdade de Motricidade Humana \\ Universidade Técnica de Lisboa \\ Portugal \\ Presidente do Fórum Olímpico de Portugal
}

\begin{abstract}
The Olympic movement today. From a diplomacy of silence to a silent diplomacy. The case of both China

Due to the political protest which scenery was Peking Olympic Games of (2008), the Olympic Movement, for paradoxical reasons, is in a crucial moment which can be the appropriate and necessary one to promote his evolution and progress. On one side, the People's Republic of Chine (PRC) promised to accomplish the necessary opening in the ambit of the respect for the Human Rights when, in 2001, Peking received the incumbency to organize the Games of the XXIX Olympiad. On the other hand, the International Olympic Committee (IOC) started to suffer the largest pressures from several non-governmental organisations (NGOs), in order to force China to accomplish his promises. Jacques Rogge recognized, that the Olympic Movement was in the middle of a crisis difficult to manage in a satisfactory way for every one involved in the process.

However, the atmosphere of crises between IOC and RPC was not an unknown situation for the two entities. As matter of fact, in the beginning of the fifties the so called "two China" problem got to a point that the national Olympic Committee of PRC, in the middle of the cold war, abandoned the IOC and several of international sports federations (IF). At the time, Avery Brundage President of IOC, affirmed that the sport has nothing to do with policy.

Passed more than fifty years, as it is possible to verify in the Olympics of Peking, the subject of the relationships between the sport and the politics, for the most several reasons, was not still resolved. On one side, the political leaders continue to manipulate the sport subjects in agreement with their conveniences, on the other hand, against all the evidences, most of leaders' of the Olympic Movement continues to affirm that the sport has nothing to do with policy.

The objective of the present rehearsal is to analyze the political subject of the sport, considering the last and present relationships between PRC and IOC, in the context of the "two China" problem.
\end{abstract}

Key-words: China, development, ideology, Olympics, policy 


\section{INTRODUÇÃO}

A atribuição da organização dos Jogos da XXIX Olimpíadai a Pequim, devido às questões relativas aos Direitos Humanos na China, à guerra no Darfur e à autonomia do Tibete, veio, mais uma vez, trazer ao decima a questão da utilização política do desporto que, recorrentemente, atinge as parangonas da comunicação social e as preocupações de muitos dirigentes desportivos. Contudo, independentemente de, só em determinados momentos, as questões políticas do desporto poderem merecer os favores privilegiados da atenção social, o que é facto é que, as mais diversas ideologias, da esquerda à direita e a generalidade dos regimes políticos, embora não o admitam, sempre que lhes convém, utilizam o desporto como uma arma política. Dum lado, esgrimem aqueles que representam os eternos complexos de uma esquerda envergonhada que gosta do desporto e dos seus efeitos propagandísticos mas, como tem preconceitos em admiti-lo, desvaloriza-o e desprestigia-o, transformando-o numa actividade menor, folclórica, à margem dos assuntos sérios da vida, pelo que, para ela, o dito só serve para alienar as desgraças do povo. Do outro lado, o apetite fogoso de uma direita mercantilista, desavergonhada, com tiques reaccionários, por vezes até mesmo fascistas, fundamentalmente interessada em transformar o desporto numa "vaca leiteira"ii que é necessário mugir até à última pinga de leite, em nome dos interesses da pátria amada.

Perante estes dois cenários, o Movimento Olímpico tradicionalmente adoptou um comportamento que invariavelmente se situou entre a metáfora da avestruz que faz por ignorar os problemas e um determinado oportunismo que procura tirar partido das situações em benefício próprio. Estas duas perspectivas, ao longo dos últimos mais de cinquenta anos, sob a desculpa do apolitismo desportivo, impediram o Comité Olímpico Internacional (COI) de possuir uma agenda política própria, acabando por, em muitas situações, andar a reboque de agendas políticas alheias e, muitas vezes até, das próprias agendas pessoais de dirigentes desportivos e políticos. Até à II Guerra Mundial, à excepção das disputas relativas ao boicote aos Jogos de Berlim (1936), a questão política do desporto, para além de alguns assuntos importantes mas, de certo modo, delimita- dos, decorreu sem problemas de maior, quer dizer, à margem das grandes questões de ordem ideológica, até porque era o COI quem controlava a situação, uma vez que a acção política decorria de dentro do COI para fora, quer dizer, do COI para os líderes, as organizações, os governos e os países com quem mantinha relações, ou desejava influenciar politicamente. iii A partir dos anos cinquenta, com as sequelas da II Grande Guerra, a situação alterou-se radicalmente na medida em que o COI começou a ter de lidar com problemas que lhe chegavam de fora para dentro. Ora, o COI não estava minimamente preparado para resolver este tipo de situações. Por isso, perante a incapacidade de lidar com problemas que estavam fora da sua esfera de acção, optou por se fechar sobre si próprio, através da posição de que o desporto nada tinha a ver com a política. Esta atitude deu origem ao designado apolitismo desportivo no qual o COI se refugiou durante mais de cinquenta anos, a fim de não se deixar contaminar pelas questões ideológicas e políticas que sempre marcaram e sempre hão-de marcar a vida mundial.

A seguir à II Guerra Mundial, as condições sociais, económicas e políticas do mundo, alteraram-se radicalmente. As relações entre o desporto e a política deixaram de ter o quadro mais ou menos cordato do passado, só verdadeiramente perturbado com os Jogos de Berlim (1936). A partir dos anos cinquenta, as questões começaram a ser outras completamente diferentes, pelo que, de um momento para o outro, o COI viu-se invadido pelos mais diversos problemas, alguns provenientes dos tempos modernos que o mundo vivia, outros, decorrentes das enormes sequelas políticas deixadas pela própria Guerra. A problemática do apolitismo desportivo começou a ser levantada por Avery Brundage (1887-1975) na qualidade de Presidente do Comité Olímpico dos Estado Unidos (COEU) a propósito do eventual boicote dos EUA aos Jogos de Berlim (1936), devido à questão dos judeus. Depois, não só na sua qualidade de Vice-presidente do COI como, de 1952 até 1972, como seu Presidente, Brundage com a maior da hipocrisias e cinismos sempre defendeu que o desporto nada tinha a ver com a política, causando com esta sua posição enormes problemas ao próprio Movimento Olímpico.iv Mas, como vamos ter a oportunidade de verificar ao longo do presente ensaio, a 
máxima adoptada por Brundage surgiu de uma incapacidade absoluta dos dirigentes enfrentarem as questões ideológicas e políticas que o desporto lhes colocava, pelo que acabaram por ser manipulados por todos os lados inclusivamente por Avery Brundage.

Depois, a II Grande Guerra Mundial acabou por colocar problemas políticos e desportivos ao Movimento Olímpico, para os quais o COI não estava preparado para resolver. Tudo aquilo que a generalidade dos dirigentes do COI verdadeiramente desejavam, era manter o Movimento Olímpico em cada país, fora do controlo governamental. Todavia, para o conseguirem, escolheram a estratégia errada. E escolheram a estratégia errada na medida em que nem todos os protagonistas de ambos os lados eram movidos pelas melhores intenções. Por isso, por paradoxal que possa parecer, para ultrapassarem os problemas políticos com que se defrontavam, ideologia era aquilo que os dirigentes do Movimento Olímpico mais necessitavam. Até porque, uma organização seja ela qual for, sem ideologia e sem uma agenda política próprias, acaba por ser gerida ao sabor das conveniências, dos impulsos e das pressões internas e externas a que, em cada momento, está sujeita. E foi o que aconteceu. Em consequência, embora contra a opinião da generalidade dos investigadores que se tem dedicado ao estudo das relações do desporto com a política, o que é facto é que a ideia de Brundage resistiu durante mais de cinquenta anos. Mas resistiu não pela força dos seus argumentos mas pela força dos interesses da generalidade dos dirigentes desportivos e políticos que passaram a utilizar a metáfora das mais diversas maneiras, em função dos seus interesses.

Em conformidade, contestamos o discurso "politicamente correcto" que afirma que o desporto nada tem a ver com a política. Este tipo de discurso, em muitas circunstâncias, conduziu injustamente o desporto em geral e o Olimpismo em particular, para uma imagem distorcida junto da generalidade das pessoas.

Agora, o Movimento Olímpico, com todos os problemas que decorreram da atribuição em 2001 da realização dos Jogos XXIX Olimpíada à cidade de Pequim, está a viver um momento crucial de mudança de paradigma, em que o velho adágio cunhado por Avery Brundage está, sob a nova Liderança de
Jacques Rogge, a dar lugar a uma outra perspectiva de entender a questão, em que o desporto é entendido como um catalizador de mudança e de progresso ao serviço do Desenvolvimento Humano.v E, devido a este novo posicionamento social e político, o que se verifica é que o COI está a evoluir de uma "política de silêncio" que caracterizou a sua acção no passado, para uma "política silenciosa" que há-de caracterizar a sua acção no futuro e que já começou a ter alguns efeitos nos Jogos de Pequim.

Na realidade, do movimento de contestação aos Jogos Olímpicos de Pequim, pode ter começado a surgir uma alternativa ao apolitismo desportivo que envolveu os discursos da generalidade dos dirigentes políticos e desportivos, sempre que lhes conveio. Porque, o que se tem vindo a passar na Olimpíada de Pequim, muito provavelmente, indicia uma mudança de paradigma em que um discurso velho e desajustado aos tempos actuais, pode estar a dar lugar a um discurso novo que assume que o desporto, tal como outra qualquer actividade do domínio social, é política pelo simples facto de estar envolvido na própria vida das pessoas e das comunidades. Nesta perspectiva, o desenvolvimento do desporto no quadro da acção do COI passa a avocar uma função catalítica de mudança no domínio do designado "soft power", que acaba por ser bem mais eficiente no que diz respeito à promoção dos valores do Olimpismo. Porque, como defende Jacques Rogge Presidente do COI, muito embora não seja função do Olimpismo resolver os problemas do mundo, todavia, também não os pode ignorar metendo a cabeça na areia, dizendo que o desporto nada tem a ver com aquilo que se passa à sua volta, para além do rendimento, da medida, dos recordes e dos espectáculos desportivos que, à escala do Planeta, acontecem de quatro em quatro anos.

Entre a institucionalização por Avery Brundage da máxima de que "o desporto nada tem a ver com a política" e a proferida por Jacques Rooge de que "o desporto é um catalizador de mudança", decorreram mais de cinquenta anos. Neste período de tempo, o mundo viveu mais ou menos convencido de que o desporto nada tinha a ver com a política até que, no início da XXIX Olimpíada, em Março de 2008, as manifestações contra a política interna e externa da Republica Popular da China (RPC), bem como contra 
a aparente passividade do COI relativamente aos atropelos aos Direitos Humanos na China, surgiram tão inopinadamente e com tanta violência, que ninguém ficou indiferente ao que se estava a passar. Tanto o COI como as autoridades chinesas foram apanhados completamente desprevenidos, perante uma situação que podia atingir proporções desastrosas para a própria organização dos Jogos Olímpicos de Pequim. Os manifestantes exigiam à RPC o respeito pelos Direitos Humanos e ao COI que assumisse a suas responsabilidades de acordo com o seu quadro ideológico de referência, expresso na Carta Olímpica.

Depois, perante a gravidade dos acontecimentos a Amnistia Internacional (AI)vi, emitiu um comunicado aonde afirmava:

"A China está a aproveitar os Jogos Olímpicos, para realizar acções de repressão que violam os direitos humanos, nomeadamente está a limpar Pequim de 'indesejáveis'. (...) A repressão sobre defensores dos Direitos Humanos, jornalistas e advogados, tem vindo a tornar-se mais forte devido aos Jogos Olímpicos. Caso as autoridades não mudem imediatamente de rumo, o legado dos Jogos Olímpicos de Pequim não será positivo para os direitos humanos na China". vii

Claro que a China repudiou as acusações da AI e defendeu a forma como o país testava a evoluir na questão dos Direitos Humanos. Não há dúvidas de que a RPC progrediu extraordinariamente desde o fim da Revolução Cultural (1966-1976), no entanto, essa evolução ficou-se em grande medida a dever às pressões das mais diversas organizações da comunidade internacional, entre elas as do COI. E não pode ser de outra maneira, até porque quando a tese do apolitismo desportivo defende a ideia da independência total da prática desportiva relativamente às questões de ordem política, transforma o desporto numa simples actividade de raiz física e biológica que se esgota no corpo máquina do rendimento, da medida e do recorde ao serviço do espectáculo. Deste modo, desencadeia uma perspectiva fascizante da prática desportiva na medida em que inverte os objectivos e os valores do desporto e, em última análise, coloca o desportista ao serviço do desporto e não o desporto ao serviço daqueles que, das mais diversas maneiras, estão ligados às suas práticas. Vasco Pulido Valente escrevia em 1988 imediatamente a seguir aos Jogos Olímpicos de Seul:

"O desporto Olímpico é um sacrifício humano aos valores mais sórdidos e perversos do mundo contemporâneo. É uma demonstração ritual de que a barbárie existe."viii

Esta constatação que vinte anos depois, como se constatou em Pequim (2008) com, entre outras, a celeuma acerca da verdadeira idade das ginastas chinesas, continua a ser oportuna, na medida em que, por detrás das performances das ginastas que encantaram o mundo, estão questões de direitos humanos nos quais se inclui a exploração do trabalho infantil, pelo que, quer os arautos do apolitismo desportivo queiram quer não, dão uma dimensão política ao fenómeno desportivo deste logo porque o colocam numa posição central no que diz respeito aos direitos humanos em geral e aos das crianças em particular. E o texto de Pulido Valente continua a ser de enorme oportunidade na medida em que tem prevalecido a ideia de que o desporto é qualquer coisa que pode funcionar à margem da política, sem quaisquer preconceitos de ordem moral para que todos aqueles que afirmam que "o desporto nada tem a ver com a política”, possam dormir descansados, porque ninguém sabe nem quer saber quantas atletas ficaram pelo caminho e, sobretudo, quais as razões. ${ }^{\text {ix }}$ Perante este quadro e as enormes pressões a que o COI estava a ser sujeito, no início da XXIX Olimpíada, Jacques Rogge foi obrigado a vir a público manifestar a posição do COI. Então, a 10/4/2008, numa conferência de imprensa realizada em Pequim, Rogge não se coibiu de recordar às autoridades chinesas os compromissos assumidos em matéria de direitos humanos aquando da escolha da cidade de Pequim para sediar os Jogos da XXIX Olimpíada. E disse:

"Pedimos claramente à China que respeite esse compromisso moral".

As declarações de Rogge suscitaram uma rápida reacção de Jiang Yu, a porta-voz do Ministério dos Negócios Estrangeiros da RPC, que pediu aos responsáveis do COI para não introduzirem política nos Jogos:

"Acredito que os membros do COI apoiam os JO e a intenção dos princípios olímpicos de não discutir factores políticos irrelevantes." "Espero que os membros do COI continuem a respeitar os estatutos olímpicos".

Quando Jiang Yu, em nome do governo da RPC, afrontou daquela maneira Jacques Rogge o COI, estava-se a esquecer ou a ignorar que os dirigentes da RPC, desde a sua fundação em 1949, sempre se 
utilizaram do desporto e do Olimpismo como instrumentos da sua estratégia política ao serviço da ideologia. Até meados dos anos sessenta, a máxima do desporto chinês que era levada às últimas consequências dizia:

"Primeiro a amizade depois a competição."

Ora, quando no desporto, a competição naquilo que significa a luta leal e honrada pela vitória, não é o alfa e o ómega da prática desportiva, é porque existem interferências externas que nada têm a ver com o próprio desporto. E foi o que aconteceu como vamos ter a oportunidade de ver ao longo do presente ensaio.

Em conformidade, o presente ensaio tem como objectivo contribuir para o esclarecimento da dimensão política do desporto, à luz do problema das "duas Chinas" que teve a sua origem ao tempo da organização dos Jogos Olímpicos de Helsínquia (1952), desenvolveu-se durante quase trinta anos influenciando a realização de vários Jogos Olímpico, sem que, ainda hoje, esteja completamente resolvido.

A questão das "duas Chinas" demorou mais do que devia a resolver, porque nunca nenhuma das partes actuou com clareza e abertura, na medida em que, sob a metáfora de que o desporto nada tinha a ver com a política, sempre se limitaram a tentar impor os seus interesses explícitos ou implícitos, próprios ou alheios.

No presente ensaio vamos analisar as relações e o percurso da RPC no âmbito do Movimento Olímpico internacional, tendo em atenção a problemática política que envolveu toda esta questão, que ficou conhecida como o problema das "duas Chinas".

\section{ABERTURA DO OLIMPISMO A ORIENTE}

Um Movimento Olímpico fechado é a última coisa que pode agradar àqueles que verdadeiramente se interessam pelas questões do Olimpismo e do desporto. Só pode convir àqueles que querem fazer do Olimpismo uma espécie de "clube de amigos", ao serviço de vários interesses que nada têm a ver nem com os atletas nem com a "celebração da humanidade". Por isso, a abertura do COI às mais diversas culturas, regiões, países e regimes, é uma questão que tem de estar sempre na ordem do dia, de acordo com o próprio espírito internacionalista do Movimento Olímpico. E a grande oportunidade para o COI dar mais um passo em frente na construção do Olimpismo moderno, aconteceu na $112^{\mathrm{a}}$ reunião do Comité Olímpico Internacional (COI) realizada a 13 de Julho de 2001 em Moscovo, quando foi anunciada a escolha de Pequim como a cidade sede dos Jogos da XXIX Olimpíada que seriam realizados em 2008. Na referida reunião, o COI:

- Arriscou a abertura ao desconhecido;

— Tomou uma decisão potencialmente portadora de futuro;

- Assumiu-se como uma instituição portadora de mudança à escala planetária;

- Proporcionou aos chineses a possibilidade de manifestarem o seu orgulho nacional;

- Desencadeou uma nova perspectiva política de abordagem das questões desportivas.

Ao tempo, foram muitos aqueles que entenderam que o COI tinha tomado uma decisão portadora de futuro. Todavia, existia também consciência de que, se por um lado, a decisão iria, de alguma maneira, contribuir para a abertura da República Popular da China (RPC) ao mundo, por outro lado, sabia-se que se estava a tomar uma decisão de alto risco, na medida em que o COI aceitava entrar num processo de longo prazox sem retorno, que, em muitas circunstâncias, não controlava. Quer dizer, o COI abriu-se por vontade própria à RPC, um país com uma população de mais de mil milhões, atribuindo a realização dos Jogos Olímpicos à cidade de Pequim que se candidatava pela segunda vez, sabendo que essa decisão, no futuro, lhe ia certamente levantar problemas difíceis de resolver. Contudo, o COI não estava em condições de não decidir a favor de Pequim, sob pena de poder ser acusado de parcialidade e de estar a introduzir questões ideológicas no processo de tomada de decisão da escolha da cidade sede dos Jogos Olímpicos.

\section{Um bilião e trezentos milhões de habitantes}

A abertura do COI a Oriente também foi uma acção interessada, na medida em que o COI é uma máquina que gere uma das indústrias mais proveitosas do mundo. Em conformidade, não podia deixar de se tentar pelo país mais populoso do mundo, com uma economia que, nos últimos trinta anos cresceu a uma taxa média anual de $9.6 \%$.xi Com um rendimento per capita de 1290 dólares, xii a RPC transformou-se 
num exército económico extraordinariamente eficiente e barato, que passou a dificultar as economias ocidentais, entre elas a dos EUA. Perante este cenário A contestação aos Jogos Olímpicos de Pequim também aconteceu certamente por motivos de interesse de ordem exclusivamente económica que nada tinham a ver com os aspectos da defesa dos Direitos Humanos que anunciavam.

\section{Receios - parlamento europeu}

Independentemente das motivações de cariz humanitário ou económico, as reacções não se fizeram esperar, mesmo antes da decisão ter sido tomada em 2001. As possíveis opções relativamente aos Jogos da XXIX Olimpíada eram:

- Pequim;

- Toronto;

- Osaka;

- Paris;

- Istambul.

Perante este número de opções, o Parlamento Europeu, com alguma antecedência, não deixou de manifestar as suas preocupações relativamente à decisão do COI, alertando-o para a necessidade de ter de:xiii

- "Estabelecer directrizes que incluíssem o respeito pelos Direitos Humanos e pelos princípios democráticos como regra geral a cumprir pelos países candidatos a acolherem os Jogos Olímpicos";

- "Proceder a uma avaliação global do impacto ambiental no que se refere, em particular, às deficiências repetidas de abastecimento de água, ao impacto do turismo de massas e às repercussões sociais na região que circunda Pequim";

- "Reconsiderar a candidatura de Pequim quando as autoridades da RPC tivessem alterado profundamente a sua política em matéria de direitos do Homem e de promoção da democracia e do Estado de Direito." Contudo, não foi por isso que o COI deixou de escolher Pequim, contrariando os desejos do Parlamento Europeu e indo contra os grupos de defesa dos Direitos Humanos que afirmavam que a RPC era uma ditadura, onde se praticavam ideias contrárias ao Olimpismo, pelo que Pequim devia ser o último lugar da Terra aonde se podia celebrar uma festa de liberdade e de fraternidade, como devem ser os Jogos Olímpicos.
E os grupos de defesa dos Direitos Humanos não tiveram qualquer pejo em avançar com o exemplo dos Jogos Olímpicos de Berlim (1936), em que o COI, de cedência em cedência, deu a sua contribuição para a hecatombe que foi a II Guerra Mundial. Os críticos argumentaram ainda com Tien An Men que, em 1993, tinha levado o COI a decidir entregar a realização dos Jogos da XXVII Olimpíada à cidade de Sydney e não a Pequim que também tinha concorrido. Como nada de verdadeiramente significativo, entretanto, mudara, não havia qualquer razão para optar por Pequim.

O que é facto é que, em 2001, prevaleceram os argumentos que em 1981 tinham determinado a escolha da cidade de Seul para a realização dos Jogos da XXIV Olimpíada. Na realidade, a atribuição dos Jogos de 1988 à capital da Coreia do Sul, coincidiu com o lento transformar de uma autocracia numa democracia. Hoje, é possível dizer que a sociedade coreana evoluiu definitivamente para uma democracia plena e a realização dos Jogos Olímpicos, de alguma maneira, contribuiu para isso. Queremos acreditar que foi nesta perspectiva que o COI entregou a realização dos Jogos da XXIX Olimpíada a Pequim.

\section{Bomba-relógio}

O mundo olímpico viveu mais ou menos sossegado, muito embora os mais atentos estivessem conscientes de que, de um momento para o outro, a bomba relógio ia rebentar. E rebentou.

Em Março de 2008, portanto no início da XXIX Olimpíada, começaram a saltar para a comunicação social as três grandes questões latentes que ameaçavam os Jogos de Pequim:

- A questão dos Direitos Humanos na China;

- A questão da guerra do Darfur;

- A questão do genocídio cultural no Tibete.

E a bomba-relógio rebentou ao desencadearem-se várias manifestações em Lhasa capital do Tibete com o propósito claro dos seus mentores se aproveitarem dos Jogos Olímpicos para chamarem a atenção do mundo sobre a situação do Tibete. Das manifestações resultaram, segundo o Governo de Pequim, 13 mortos e 325 feridos e, segundo o Governo tibetano no exílio, pelo menos, 99 mortos, a maioria na própria capital.xiv 
Depois, o percurso mundial da Tocha Olímpica criou uma excelente oportunidade para diversas Organizações Não Governamentais (ONGs) se manifestarem contra o que se estava a passar na RPC. E tudo começou logo na cerimónia do atear da Chama Olímpica realizada em 24 de Março de 2008 em Olímpia, já que o mundo teve a oportunidade de assistir em directo na televisão, a manifestações em defesa dos direitos dos tibetanos, levadas a efeito pela ONG Repórteres sem Fronteiras (RSF).

\section{Uns Jogos excepcionais}

Perante o impacto das manifestações, diversos dirigentes políticos e desportivos apressaram-se a manifestar a sua contrariedade relativamente ao que se estava a passar. Segundo eles, não era legítimo que diversas ONGs se imiscuíssem nos Jogos Olímpicos com os quais nada tinham a ver. Contudo, não fazia qualquer sentido que o COI, por um lado, assumisse os Jogos Olímpicos como um ritual à escala do planeta, em que pretendia "celebrar a humanidade", mas, por outro, se tenha permitido, ao longo dos últimos cinquenta anos da sua existência, conviver com as maiores misérias do mundo, sustentando invariavelmente a sua posição numa declaração hipócrita como aquela que diz que "o desporto nada tem a ver com a política".

Na realidade, perante as enormes transformações sociais que aconteceram desde os Jogos de Atenas 2004, para além dos problemas políticos e económicos que envolvem o mundo e, em especial, a China, só os ingénuos podiam supor que a Olimpíada de Pequim bem como os Jogos Olímpicos, iam decorrer sem problemas, quer dizer, numa espécie de paz celestial. Assim, a abertura do COI a Oriente, foi uma espécie de risco calculado, que só o futuro poderá fazer a contabilidade dos custos benefícios de tal opção, na certeza de que, o Olimpismo nunca mais será o mesmo depois dos Jogos Olímpicos de Pequim. O COI ao escolher Pequim para sediar a organização dos jogos Olímpicos, apostou, arriscou e, para já, ganhou. Os Jogos decorreram na maior das harmonias e foram, como Jacques Rogge teve a oportunidade de referir, sem sombra de dúvidas, um acontecimento desportivo que, de facto, apesar de tudo, celebrou a humanidade. O Presidente do COI considerou que o organismo que lidera "saiu reforçado" da China:
"Foram jogos excepcionais em termos de universalidade".xv Todavia, a Olimpíada de Pequim vai continuar até ao dia 31 de Dezembro de 2011, pelo que todo o processo em curso vai continuar. O que é que se vai passar na China durante esse período de tempo é a pergunta a fazer. Do ponto de vista interno e externo, qual é o legado político, económico e social dos Jogos Olímpicos de Pequim?

Vamos ter de esperar algum tempo para nos apercebermos do significado da decisão de 2001 tomada pelo COI.

\section{O DESPORTO AO SERVIÇO DA RPC}

Jiang Yu, porta-voz do Ministério dos Negócios Estrangeiros da RPC, em plena crise originada pela contestação à política chinesa durante o percurso da Tocha Olímpica, veio recordar ao mundo umas das realidades mais hipócritas do desporto, isto é, que o desporto nada tem a ver com a política quando as circunstâncias não jogam a favor dos nossos interesses, e, tem tudo a ver com a política, quando elas jogam a nosso favor. E esta dualidade de critérios, foi o que sempre aconteceu na RPC.

Hoje, é possível saber que, as autoridades da RPC até ao final da Revolução Cultural (1966-1976), subordinaram a competição desportiva aos desígnios da orientação política. Ao fazê-lo, perverteram o espírito do desporto. Mas é necessário dizer que os dirigentes da RPC ao utilizarem o desporto como arma política, não faziam nada mais do que os dirigentes de todos os outros países, na medida em que esse procedimento sempre foi utilizado pela generalidade dos políticos dos mais diversos países do mundo e de todos os regimes. O grande problema é que, se por um lado, a generalidade dos dirigentes políticos nunca teve grande respeito pelo desporto e os seus dirigentes, por outro lado, a generalidade dos dirigentes desportivos nunca se deu muito a respeitar.

Em conformidade, todos eles só não utilizaram o desporto em benefício dos seus interesses políticos quando o não puderam fazer. Umas vezes, fizeramno com bons propósitos, outras vezes, nem por isso. Porém, quando as coisas não iam no sentido que mais lhes interessava, começavam logo a acusar os seus opositores de utilização política do desporto, dizendo que o desporto nada tinha a ver com a política. 


\section{Espanto, admiração e receio}

$\mathrm{Na}$ realidade, o desporto tem e muito a ver com a política e as autoridades chinesas até têm uma longa experiência acerca do assunto. Toda a estratégia da candidatura e organização dos Jogos da XXIX Olimpíada, assentou na necessidade política de afirmação da RPC no mundo, processo iniciado ainda ao tempo de Mao Zedong (1893-1976) com a diplomacia do ping-pong, muito embora o desejo dos chineses organizarem o Jogos Olímpicos viesse de princípios do século XX. A própria entrada da RPC nas Nações Unidas, sempre foi vista pela autoridades chinesas como uma questão que andava a par da entrada no COI. E porquê? Pelo problema da "duas Chinas", uma disputa que se desenvolveu no COI durante mais de 30 anos e que ainda hoje não está completamente resolvida. Se alguma coisa esta disputa prova, é que o desporto e a política estão completamente envolvidos um no outro.

Na realidade, as autoridades da RPC sempre utilizaram Olimpismo como um instrumento da sua afirmação no mundo. Mais recentemente, desde o pingpong de Mao Zedong, passando pela primeira candidatura falhada da cidade de Pequim à organização dos Jogos Olímpicos da XXVII Olimpíada que acabaram por se realizar em Sydney, até à candidatura vitoriosa de Pequim para a organização dos Jogos da XXIX Olimpíada, continuaram a fazê-lo de uma forma bem empenhada, mas debaixo de uma desconfiança crescente por parte da comunidade internacional, na medida em que ninguém é capaz de concluir se o estão a fazer com bons ou maus propósitos. Hoje, o mundo olha com espanto, admiração e algum receio para a China e aguarda com expectativa as consequências a prazo, tanto do ponto de vista interno como externo, que hão-de decorrer dos Jogos de Pequim.

O que parece já não haver dúvidas é que o desporto, de há uns anos a esta parte, no mundo globalizado em que vivemos, passou a ser um instrumento de "soft power" da geopolítica chinesa. Em boa verdade, ninguém pode prever o que vai ser a China depois dos Jogos. Porém, uma coisa parece certa, o desporto é para os chineses um instrumento da sua afirmação no mundo, pelo que a desconfiança com que alguns olham para os grandes eventos desportivos em que a RPC se envolve, é absolutamente justi- ficada até pelos ensinamentos que é possível colher da história recente.

\section{Países de língua oficial Portuguesa}

O sentimento de desconfiança referido é, também, partilhado por muitos daqueles que nos Países de Língua Oficial Portuguesa (PALOPs) se interessam pelas questões do desenvolvimento do desporto. A primeira edição dos Jogos da Lusofonia decorreu na Região Administrativa Especial de Macau, entre 7 e 15 de Outubro de 2006. Segundo os seus promotores, com o objectivo de celebrarem:xvi

"O espaço da lusofonia como comunidade de afinidades construídas em redor de uma mesma língua".

No entanto, a realidade é completamente diferente. A institucionalização dos Jogos da Lusofonia mais não é do que um muito útil e adequado instrumento ao serviço de uma estratégia de afirmação da China no continente africano, e muito especialmente em Angola e Moçambique. Para atingir este desiderato a RPC fez um investimento de 160 milhões de patacas ou seja cerca de 16 milhões de euros na realização dos Primeiros Jogos da Lusofonia.

Nesta perspectiva em que os Jogos da Lusofonia são pura e simplesmente uma alavanca estratégica da afirmação da RPC em África, pelo que Portugal através do COP está a ser simplesmente um peão daquela estratégia, sem que daí advenham quaisquer resultados desportivos, devido ao desnível competitivo entre as equipas dos diversos países e regiões participantes, xvii ou quaisquer outros dignos de nota. Por outro lado, ao abrir os Jogos da Lusofonia a outros espaços geográficos aonde Portugal impôs uma presença colonial, pode ser contraproducente na estratégia de afirmação de Portugal no mundo. O que se passa por exemplo em Goa quando o Presidente da República Cavaco Silva recebeu em 2007 sob protestos um Doutoramento Honoris Causa pela Universidade de Goa, até às manifestações de Outubro de 2008 de protesto por parte da "freedomfighters fraternity", que acusam Portugal de estar a desenvolver uma política colonialista e a Fundação Oriente de ser um agente ao serviço do Governo Português, são aspectos que devem ser considerados sob pena de "o feitiço se virar contra o feiticeiro". Nesta perspectiva, também o Brasil, pelo menos aparentemente, olhou para a primeira edição dos Jogos 
da Lusofonia com alguma desconfiança. Aguarda-se com interesse, a posição que irá tomar relativamente à segunda edição dos Jogos que decorrerá em Portugal em 2009, para a qual o governo português consagrou no Orçamento de Estado a verba de 1,44 milhões de euros, absolutamente insignificante se comparada com a dispendida pelos chineses na primeira edição dos Jogos da Lusofonia.

\section{Os guerreiros de terracota}

Apesar de tudo, os Jogos da Lusofonia são só um pequeno aspecto da estratégia de "soft power" de afirmação da RPC no mundo. No que diz respeito ao grande projecto que foram os Jogos de Pequim, se tudo começou na monumentalidade das infra-estruturas desportivas e para-desportivas, não é por isso que os chineses deixaram de cuidar de todos os lados da organização até ao mais ínfimo pormenor, numa lógica de integração vertical de uma cadeia de valores políticos, económicos e comerciais, que chegou até ao detalhe dos equipamentos que os atletas olímpicos usaram durante os Jogos, fornecidos pela NIKE o que, desde logo se revela uma atitude de simpatia para com os americanos, na medida em que na China existe uma marca semelhante à NIKE que dá pelo nome de Ni Ling.

O Estádio Olímpico - Ninho de Pássaros - com uma capacidade para 91 mil espectadores e um custo de 425 milhões de dólares, mostrou ao mundo uma nova China rica e moderna, bem diferente da China pobre e miserável transmitida nos anos sessenta e setenta pelas televisões de todo o mundo. Mas a monumentalidade das instalações desportivas projectou-se até ao nível da acção no terreno, através dos equipamentos. Repare-se que os equipamentos que os atletas chineses utilizaram, foram inspirados nos célebres guerreiros de Terracota. Eles procuram transmitir os sentimentos de patriotismo e sacrifício que o lendário imperador Qin Shi Huangdi promoveu para a unificação da China. Os atletas afirmavam que quando vestiam os equipamentos se sentiam na pele de "super-heróis", na medida em que:

- Incorporavam o espírito guerreiro de Terracota;

- Sentiam um enorme orgulho em pertencerem à equipa nacional;

- Usufruíam do supremo sentimento de servirem o país.
Para que tudo isto pudesse ser explorado ao máximo, o vermelho dos equipamentos foi testado sob os efeitos da iluminação das transmissões televisivas no próprio Estádio Olímpico, a fim de ser conseguida a cor mais desejada. Mas havia ainda um segredo bem guardado que procurava atingir o íntimo de cada atleta. No interior dos equipamentos, num local onde ninguém a não ser o próprio podia ver, estavam escritas duas palavras do Hino Nacional da RPC:

"Levantem-se e marchem...". xvii

Os chineses idolatram os seus atletas mais famosos, desde Liu Xiang, ouro em Atenas nos 110 metros barreiras, até a Yao Ming, jogador de basquetebol da NBA. Assim, perante o desafio dos Jogos Olímpicos, a RPC preparou-se para os vencer porque, actualmente, ao contrário do passado, as vitórias desportivas passaram a fazer parte da afirmação política e económica da RPC no mundo.

\section{Uma Educação Física ao serviço da Pátria}

Hoje, a RPC voltou à linha dura da competição desportiva de Mao Zedong (pré-marxista), quer dizer, dos seus tempos de juventude. $\mathrm{O}$ "grande timoneiro" da revolução chinesa, em 1917, muito antes da sua visão marxista do mundo, escreveu um livro intitulado "Um Estudo de Educação Física", aonde começava por lamentar a deficiente condição física da população chinesa. E, depois, escreveu: "A educação física não só harmoniza as emoções como também fortalece a vontade. (...) O principal desígnio da educação física é o heroísmo militar. Os objectos do heroísmo militar como a coragem, desafio, audácia e perseverança são todos questões de vontade. (...) As corridas de longa distância são particularmente boas para o treino da perseverança." xix

Note-se que, por contraditório que possa parecer, esta visão desportiva de Mao Zedong até era coincidente com a do nacionalista Chiang Kai-shek. E de tal maneira que, segundo Andrew Morris (2008), xx nos anos trinta aconteceram várias tentativas para encontrar na China um modelo desportivo nacional que pudesse contribuir para a unidade do país. $\mathrm{E}$ esta ideia era partilhada tanto à esquerda como à direita. Aliás, a confusão entre diferentes perspectivas ideológicas de direita e de esquerda aconteceu também em França nos anos trinta.xxi 
Assim, nesta política de afirmação nacionalista, a partir dos términos da Revolução Cultural, a RPC desenvolveu toda uma estratégia conducente à obtenção de resultados desportivos que se projectassem no mundo em benefício do país. Em consequência, nos Jogos de Atlanta (1996) ficou em quarto lugar com 16 medalhas de ouro; em Sydney (2000) ficou em terceiro lugar com 28 medalhas de ouro; em Atenas (2004) ficou em segundo lugar com 32 medalhas de ouro (três atrás dos EUA); em 2008 em Pequim a China ficou em primeiro lugar com 51 medalhas de ouro num total de 100 medalhas conquistadas.

\section{Ser rico é glorioso}

A guerra, em muitas circunstâncias, já não acontece entre os exércitos dos países. Agora, a verdadeira "guerra" é económica. Em conformidade, a RPC assumiu decididamente o pensamento do antigo Primeiro-ministro Deng Xiaoping quando este deu o sinal de partida, quer dizer, o mote, para o combate económico que se avizinhava:

"Ser rico é glorioso".

Do ponto de vista interno a RPC na última década criou uma classe média de 100 a 150 milhões de pessoas com possibilidades para comprarem casa, automóvel e outros bens, até há pouco tempo inacessíveis. Do ponto de vista externo, os Jogos Olímpicos de Pequim ao provocarem a visita de mais de 500 mil turistas e, entre os dias 8 a 24 de Agosto, a atenção de 4,7 biliões de telespectadores, ou seja, cerca de $70 \%$ da população da Terra, foram bem um marco fundamental de toda uma estratégia de promoção e afirmação política e económica da RPC no mundo. A Organização Mundial do Turismo estima que a China deve atingir o topo da lista de países mais procurados pelos turistas até 2010 .

Hoje, não restam dúvidas que a realização dos Jogos Olímpicos com uma organização perfeita aos olhos do mundo, era de fundamental importância para a imagem da China. Contudo, perante os perturbadores acontecimentos relativos ao percurso da Tocha Olímpica, as autoridades chinesas não podiam proclamar que o desporto nada tem a ver com a política, na medida em que elas, sempre o utilizaram como um dos seus "feitiços" para resolverem questões, económicas, sociais e políticas, com que se deparavam.
De facto, ao longo dos últimos quase sessenta anos, Mao Zedong, Zhou Enlai (1898-1976), Deng Xiaoping (1904-1997) e agora Hu Jintao (n.1942) nunca deixaram os créditos do desporto por mãos alheias. Sempre que lhes conveio envolveram o desporto nas questões políticas e utilizaram-no de acordo com a estratégia que mais convinha ao país.

\section{REGRESSO AO PASSADO}

Mas se Jiang Yu, em nome do governo da RPC, ao afrontar o COI, estava a ignorar o passado recente da RPC, em que o desporto se transformou no instrumento político do domínio do "soft power" que do ponto de vista interno contribui para a construção da identidade nacional sem a utilização da violência do passado, do ponto de vista externo está também a ser um instrumento poderosíssimos de "soft power" de afirmação da RPC no mundo, no que diz respeito ao passado mais longínquo, Jiang Yu também se esqueceu que o chineses sempre tiveram uma afinidade muito especial relativamente ao Movimento Olímpico e ao COI.

\section{A humilhação colonial}

Em finais do século XIX a China era um país subjugado aos interesses das principais potências coloniais. O domínio colonial exercia-se com o apoio e a conivência dos imperadores chineses da dinastia Manchu que governavam a China desde o século XVII. A revolta era uma questão de tempo. Em 1900, os Boxers, membros de uma sociedade secreta que praticava o "boxe sagrado", desencadearam uma revolta nacional contra os estrangeiros. Acabaram por ser massacrados pelos exércitos das potências coloniais.

Em 1911, o movimento nacionalista liderado por Sun Yat-sen derrubou a dinastia Manchu e a república foi proclamada. Sun Yat-sen acabou por ser o primeiro Presidente da República. Depois, com os seus apaniguados, fundou o Kuomintag, Partido Nacional do Povo. Todavia, a república não conseguiu fazer frente nem às potências estrangeiras, nem aos chefes militares locais, os "senhores da guerra".

Toda a lógica da evolução do desporto na China tem de ser entendida a partir da humilhação colonial sofrida no século XIX. O desporto na China durante o último século serviu para demonstrar o seu poder 
político e social, mas também para demonstrar a sua profunda ansiedade relativamente a um passado que a feria profundamente. Nestes termos, o processo de desenvolvimento do desporto na China foi uma questão central do chamado problema das "duas Chinas", na medida em que sempre esteve relacionado com a sua identidade e dignidade nacionais.

\section{Guerra civil e cisão}

Em 1921, foi criado o Partido Comunista Chinês (PCC). Os seus principais fundadores foram o intelectual Chen-Tu-xiu, o educador Peng-Pai e o activista político Mao Zedong. Depois, em 1927, o general Chiang Kai-shec assumiu o comando do Kuomintag, disposto a criar ordem no país. Mas, ao atacar os "senhores da guerra", acabou também por atacar os comunistas o que desencadeou um conflito de enormes proporções. Os comunistas estavam numa posição desvantajosa, por isso, Mao Zedong, para evitar o cerco, dirigiu-se para Norte para a província de Shensi, através de uma operação que ficou conhecida como a "Longa Marcha".

A guerra entre nacionalistas e comunistas só foi interrompida em 1937 a fim de ambos os exércitos combaterem o Japão que havia invadido a

Manchúria, e durante a II Guerra Mundial a fim de enfrentarem as forças Nazis.

Com o final da II Guerra Mundial, os japoneses foram expulsos do território chinês e as tropas de Chiang Kai-shec, com o apoio dos EUA, lançaram uma ofensiva contra exército popular de Mao Zedong. Apesar do apoio dos EUA a Chiang Kaishec, as tropas de Mao acabaram por vencer e, em $1^{\circ}$ de Outubro de 1949, proclamaram a República Popular da China (RPC).

Chiang Kai-shec, financiado e armado pelos EUA, refugiou-se na ilha de Taiwan (Formosa), onde instalou o governo da República da China (RC) com a capital em Taipé. No continente, ficou a RPC liderada por Mao Zedong. A RC (Taiwan) passou a ser composta pelas ilhas de Taiwan, Pescadores, Kinmen, Matsu e outras menores. Na China continental, organizou-se a RPC, que hoje incluiu as regiões administrativas especiais de Hong Kong e Macau.

O problema é que se por um lado a RPC considerava Taiwan como uma província da China, quer dizer, como parte do seu território soberano, pelo que a
RC era uma entidade extinta, pelo que ilegítima, por outro lado, a RC reivindicava a supremacia sobre toda a China, na medida em que era o Kuomintag que governava a China, quando foi forçado a transferir-se para Taiwan em Dezembro de 1949, depois de ter perdido a guerra civil com o exército de Mao. E assim, se originou aquilo a que ficou conhecido pelo problema das "duas Chinas", que acabou também por ter significativas incidências no mundo do desporto e do Olimpismo.

\section{"Realpolitik"}

Se até 1971 a Organização das Nações Unidas (ONU) reconhecia a RC, a partir de 1971, através da resolução 2758 \{XXVI\} de 25 Outubro da Assembleia-geral, passou a reconhecer a RPC da China como o único representante da China nas Nações Unidas.xxii De facto, em 1971, a RC (Taiwan) perdeu o seu lugar na ONU tendo o mesmo sido ocupado pela RPC. Desde então, a ONU considera Taiwan como uma província da China. Depois, a "realpolitik" determinou que a maioria dos Estados acabasse por transferir o seu reconhecimento diplomático para a RPC, passando a considerar esta última como o único representante legítimo da unidade chinesa. Contudo, a RC continuou a manter relações oficiosas com quase todos os países do mundo, incluindo a própria RPC.

O desporto, como não podia deixar de ser, sempre esteve no meio das "duas Chinas", pelo que as questões desportivas nunca foram fáceis de gerir. Os paradoxos e as contradições próprias da política, envolveram as questões desportivas e estas, por sua vez, atiçaram as próprias contradições políticas. Mas também no desporto imperou a "realpolitik" na medida em que, hoje, Taiwan é conhecida como China Taipé nos eventos desportivos internacionais tais como os Campeonatos do Mundo, Jogos Asiáticos e Jogos Olímpicos. Tudo o resto funciona dentro da ambiguidade da "realpolitik". Por exemplo, o basebol é considerado a modalidade nacional em Taiwan. A fase final que apurava para os Jogos de Pequim, realizou-se em Março de 2008 precisamente em Taiwan. Tudo sem quaisquer problemas.

Contudo, quando o COI divulgou o percurso da Tocha Olímpica, verificou-se que ia do Vietname (Cidade de Ho Chi Minh) para Taipé, antes de passar 
por Macau e Hong Kong. Taiwan rejeitou que a Tocha Olímpica passasse por Taipé na medida em que, nestas circunstâncias, seria reconhecer que Taiwan é parte integrante da RPC.

Este é o espírito de convivência e gestão de ambiguidades que anima as relações entre as "duas Chinas". Para além de Taiwan participar nos próximos Jogos Olímpicos de Pequim com uma comitiva própria, muitos atletas de delegações de Taiwan têm competido com atletas de delegações da RPC em múltiplos eventos internacionais, sem que, até Maio de 2008, tenham existido relações oficiais directas entre a RPC e Taiwan.

Entretanto, em Abril de 2008, aconteceu um encontro histórico entre o líder da RPC, Hu Jintao e o Vice-presidente eleito da RC, Vicent Siew. Foram as necessidades da economia a determinar esta abertura de relações e o desporto com os Jogos Olímpicos a fazer de catalizador a fim de que o processo químico se desencadeasse como pretendido. "Boa química, química harmoniosa" foram as palavras de um membro da delegação taiwanesa ao comentar a reunião.xxiii

Hoje, existem diferentes opiniões jurídicas sobre o estatuto político da RC pelo que, o que melhor caracteriza a situação é a ambiguidade. Taiwan, tem partidos, eleições e governo próprio, está representada em diversas organizações internacionais e negoceia com praticamente todos os países do mundo, incluindo a própria RPC sem que, aparentemente, seja posto em causa o princípio da unidade chinesa ou em questão a autoridade de Pequim. A política do real tomou conta da situação. Recentemente, iniciaram-se contactos directos entre o RPC e Taiwan e, em Julho de 2008, efectuou-se o primeiro voo de Taiwan para o continente desde 1949.

\section{A CHINA E O MOVIMENTO OLÍMPICO}

O envolvimento da China nas questões do Olimpismo começou, tal como começou em muitos outros países, pela iniciativa de Pierre de Coubertin. Em 1894, Coubertin, através da embaixada francesa na China, enviou uma missiva aos governantes da dinastia Manchu convidando-os a enviarem representantes aos Jogos Olímpicos de Atenas (1896). Contudo, Coubertin não obteve qualquer resposta na medida em que os chineses não estavam familiariza- dos com as questões do Olimpismo. Depois: — Em 1904, a imprensa chinesa relatou algumas estórias sobre os Jogos de St. Louis nos EUA; - Em 1906, apareceu numa revista local um artigo acerca da história do Olimpismo;

— Em 24 de Outubro de 1907, o pedagogo Zhang Boling realizou uma conferência em Tianjin que se seguiu a um evento desportivo, tendo defendido a participação chinesa nos Jogos Olímpicos independentemente dos resultados;

- Em 1915, o COI convidou a China a pertencer ao Movimento Olímpico Internacional e a enviar alguém às suas reuniões. xxiv Wang Cheng-ting, por diversas vezes entre 1932 e 1939 Ministro dos Negócios Estrangeiros, um dos fundadores em 1913 da Federação Atlética Amadora Nacional Chinesa, organismo que foi o motor de arranque do desporto na China, responsável pela organização em 1921 dos Jogos do Extremo Oriente em Changai, foi cooptado em 1922 para membro do COI. Em 1924, os chineses participaram extra-programa nos Jogos Olímpicos de Paris e, em 1928, mandaram observadores aos Jogos de Amesterdão. O Comité Olímpico Nacional Chinês (COC) acabou por ser fundado em Pequim e inscrito no COI em 1931. Ainda segundo o site do actual COC da RPC, a China só foi realmente convidada pelo COI para participar nos Jogos Olímpicos de Los Angeles em 1932. De facto, a China foi aos Jogos Olímpicos em Los Angeles com uma delegação de seis elementos. Em 1936, apresentou-se em Berlim com uma comitiva de 139 elementos.

Em 1939 e em 1947, o membro chinês do COI, Wang Zhengyan, propôs ao COI a entrada de novos elementos chineses. Eles foram respectivamente H.H. Kung (Kong Xiang-si) Presidente do Banco da China e Shou Yi Tung (Dong Shouyi) (1895-1978) um professor de educação física, secretário-geral do COC, cooptado na $41^{\text {a }}$ Sessão do COI, realizada em Estocolmo de 18 a 21 de Junho de 1947.

Em 1946, o COC tinha a sua sede em Xangai e em 1947 mudou-se para Nanquim, sendo, ao tempo, o Prof. Shou Yi Tung o seu secretário.xxv Com a proclamação da RPC por Mao Zedong em 1 de Outubro de 1949, o governo militar de Chiang Kai-shek retirouse para Taiwan. A maioria dos membros do COC que, antes da II Guerra Mundial, tinha sido reconhe- 
cido pelo COI, foram para Taiwan, pelo que o COC passou a funcionar em Taipé.

\section{Novos tempos e problemas}

Depois da Revolução Chinesa e da fundação da RPC em 1949, o COI recebeu do COC a informação de que a sua direcção se tinha mudado para Taipé em Taiwan aonde, como se disse, sob a liderança do general Chiang Kai-shec, se organizou a China Nacionalista debaixo da protecção dos EUA. Para Avery Brundage, ao tempo Vice-presidente do COI, a mudança não levantou quaisquer problemas no COI, pelo que a ocorrência foi registada nos escritórios da organização em Lausanne, como:

"Um acto rotineiro ao qual não foi atribuído nenhum significado político" xxvi

Contudo, esta informação que Brundage verteu para as suas memórias, levanta sérias dúvidas, na medida em que o mundo tinha acabado de viver a maior hecatombe da sua história e olhava para o que se passava na China com desconfiança e preocupação. Muito embora a ONU tenha continuado a reconhecer o governo de Taipé como legitimo representante da China, o que é facto é que se estava perante uma situação muito melindrosa que não podia ser tratada como um simples acto de rotina administrativa. Esta perspectiva é defendida por Xu Guoqi (2008)xxvii quando afirma que o facto de Taiwan ter continuado no seio da "Família Olímpica" tem sobretudo a ver com a conjuntura da "guerra-fria", até porque muitos países ocidentais, até 1970, reconheciam o governo de Taipé em prejuízo do governo de Pequim. Em conformidade, hoje, parece não haver dúvidas que a questão foi tratada pelo COI com alguns preconceitos relativamente à RPC, em defesa dos interesses de Taiwan, cujo governo era protegido pelos EUA. Entretanto, os problemas não se fizeram esperar.

\section{Federação Atlética Amadora de Toda a China (FAATC)}

Em 1951, um ano antes dos Jogos de Helsínquia (1952), fundou-se na RPC a Federação Atlética Amadora de Toda a China (FAATC) que se considerava a si própria como a legítima representante do Movimento Olímpico em toda a China.xxvii Em conformidade, o COI recebeu uma carta de Pequim aonde se dizia que o CON estava formado, pelo que desejava ser reconhecido pelo COI a fim da RPC poder participar nos Jogos Olímpicos a realizar na Finlândia (1952). O Comité Organizador dos Jogos de Helsínquia também recebeu uma carta através da embaixada chinesa em Estocolmo, aonde era solicitado um convite para a RPC participar nos Jogos da XV Olimpíada. O Comité Olímpico Chinês com sede em Taipé (Taiwan) também solicitou um convite a fim de participar nos Jogos de 1952.

Depois, durante os trabalhos da $47^{\text {a }}$ Sessão do COI realizada em Oslo em 12 e 13 Fevereiro de 1952, o então Presidente do COI o sueco Sigfrid Edström teve uma reunião com o representante da FAATC, em que o dirigente chinês o informou que a sua Federação representava o Movimento Olímpico para toda a China, pelo que desejava ser reconhecida pelo COI a fim de participar nos Jogos de Helsínquia (1952). Edström prestou-lhe todas as informações necessárias inclusivamente acerca dos pré-requisitos necessários para que o CON da RPC pudesse ser aceite como membro do COI.xxix

Como nenhum dos três membros chineses do COI compareceu à reunião, Edström informou ainda o representante da FAATC que desejava consultar os chineses membros do COI.

\section{Má Vontade}

Da reunião de Sigfrid Edström com o representante da FAATC transparece alguma má vontade contra os Chineses da RPC, protagonizada por alguns membros do COI, para a qual não vemos outros motivos senão políticos, na medida em que existiam enormes preconceitos contra o regime comunista da RPC. Na realidade, ao tempo, não fazia qualquer sentido colocar as exigências que foram colocadas à RPC, como a questão das Federações Internacionais terem de ter representantes da RPC, um país acabado de sair de uma guerra com os japoneses havia sete anos e de uma guerra civil havia pouco mais de dois anos. Apesar destas dificuldades, o COI decidiu que se as Federações Internacionais não respondessem na sua maioria afirmativamente à questão, o CON da RPC não seria convidado a participar nos Jogos de Helsínquia.

Por outro lado, ao desejar consultar os membros chineses do COI que eram três, Edström, secundado por Avery Brundage, ao tempo vice-presidente do $\mathrm{COI}$, sabia que as moradas eram desconhecidas, o 
que tornava a situação ainda mais risível. Por outro lado, os membros do COI eram e são cooptados pelo próprio COI. Eles não representavam nem representam no COI o país da sua nacionalidade. Eles eram os representantes, quer dizer, os embaixadores do COI na China. Por isso, os membros chineses do COI estarem ou não presentes era um problema do COI e não da RPC. Ainda hoje, os membros do COI só representam os interesses do próprio COI no país onde habitam.

Na versão de Karl Lennartz (1995),27 Edström reuniu-se com o representante da FAATC mas como não se sabia se as Federações Internacionais tinham federações da RPC filiadas e o reconhecimento dos CONs era por via das Federações Internacionais, o COI acabou por não tomar naquele momento qualquer decisão. Ainda segundo Lennartz, Avery Brundage, manifestou a opinião de que deviam ser consultados os membros chineses do COI, antes de haver qualquer decisão.

Segundo as memórias de Brundage (1976), 26 com o objectivo de resolver a filiação da RPC no COI, Sigfrid Edström reuniu-se com os chineses. Contudo, iniciada a reunião, ao verificar que estava perante entidades políticas representantes do governo, Edström recusou-se a falar com elas sobre questões desportivas. Para além do mais, Edström informou os chineses presentes que desejava, antes de tudo, falar com o único membro chinês do COI que ainda vivia na China continental, o Prof. Shou Yi Tung.

\section{Prof. Shou Yi Tung}

O Prof. Shou Yi Tung não tinha respondido às tentativas de contacto de Sigfrid Edström. Aliás, segundo Xu Guoqi (2008) 27 os dirigentes de Taiwan tinham posto a correr o boato de que ele tinha morrido. De qualquer maneira, a questão da RPC, não devia ser resolvida sem ouvir o único membro chinês do COI que se sabia ter ficado na China continental depois da revolução, se tal fosse possível. Esta era a posição de Edström e Brundage. Mal sabiam eles que o tiro lhes ia sair pela culatra.

O Prof. Shou Yi Tung, foi um desportista eclético, membro das equipas nacionais de basquetebol, futebol, basebol, atletismo e ténis. Esta variedade de modalidades ficou-se muito provavelmente a dever ao facto de ter sido durante dois anos estudante no Springfield College (Manssachusetts - EUA). Depois, foi capitão e mais tarde em 1934/36, treinador da equipa nacional de basquetebol, tendo participado na qualidade de treinador nos Jogos Olímpicos de 1936. Foi árbitro internacional da FIBA. Em 1944, foi nomeado secretário-geral da Federação Amadora Atlética Nacional Chinesa que, com sede em Nankin, cumpria as funções do Comité Olímpico Nacional Chinês. O Prof. Shou Yi Tung acabou por instalar a sede do Comité Olímpico Nacional Chinês em Nankin, tendo sido seu vice-presidente. Em 1948, foi secretário-geral da delegação chinesa aos Jogos de Londres. Enquanto professor de educação física, foi director do Instituto de Educação Física da Young Men's Christian Association (YMCA) em Tien Tsin. Foi, ainda, de 1947 a 1958, membro do COI. Quer dizer, o Prof. Shou Yi Tung apresentava um currículo desportivo muito significativo pelo que era uma pessoa intransponível no quadro da integração da RPC no Movimento Olímpico, desde logo e para além de tudo, porque era membro de pleno direito do COI. $\mathrm{xxx}$

Ao decidir, em 1949, ficar na RPC, ao contrário dos outros dois elementos chineses membros do COI, o Dr. H. H. Kong e o Dr. C. T. Wang que aderiram à China Nacionalista, o Prof. Shou Yi Tung acabou por se tornar o principal protagonista de uma das páginas mais confusas do Movimento Olímpico Internacional que tem precisamente a ver com o chamado problema das "duas Chinas".

\section{Duas Chinas e duas equipas}

Os Jogos Olímpicos de Helsínquia (1952) aproximavam-se e os chineses da RPC não esperaram pelo convite para se fazerem convidados. O que aconteceu foi que em antevésperas dos Jogos a equipa olímpica da RPC aguardava em Estalinegrado autorização para entrar na Finlândia. A situação no que diz respeito ao problema das "duas Chinas" era extraordinariamente melindrosa. Sigfrid Edström começou por recordar aos membros do COI que:

"A organização Olímpica deve ignorar as questões raciais, religiosas, ou políticas, o seu fim é a união da juventude do mundo."xxxi

Segundo Lennartz, ${ }^{27}$ Sigfrid Edström informou que muito embora só a China da Formosa (Taiwan) tenha sido convidada para participar nos Jogos, toda- 
via, a Comissão Executiva tinha tomado a posição de não permitir que qualquer das Chinas participasse nos Jogos. Perante a dureza de tal decisão, houve quem se manifestasse contra, argumentando que já havia Federações Internacionais (FI) aonde estavam inscritas Federações Desportivas da RPC. Em conformidade, a Comissão Executiva do COI decidiu ouvir cada um dos representantes das "duas Chinas". O de Taiwan, Sun-hoh Gun, argumentou que 19 dos 25 membros do COC viviam em Taiawn o que legitimava a continuidade do próprio Comité Olímpico Nacional Chinês na RC. O representante da RPC Cheng Chi-pai, para além de se declarar o representante legal do Prof. Shou Yi Tung, contra-argumentou afirmando que falava em nome de 400 milhões de chineses, pelo que pediu que o seu CON fosse o único reconhecido pelo COI, uma vez que as federações internacionais de futebol, natação e basquetebol, já tinham federações da RPC. Segundo Xu Guoqi (2008) ${ }^{26}$ as referidas federações tinham entrado nas federações internacionais na medida em que se tinham disponibilizado para pagar as quotas em atraso das antigas federações chinesas. Entretanto, Cheng Chi-pai pediu também a imediata expulsão do COI, do CON-Taiwan. Edström acabou por concluir que, das duas uma:

- "Ou nenhum dos comités nacionais podia participar nos Jogos de Helsínquia";

- "Ou os dois comités nacionais podiam participar nos Jogos de Helsínquia".

A segunda hipótese ganhou 29-22.

Na sequência da votação, o francês François Piétri fez a seguinte proposta aprovada por 33 de 53 votos: "O COI, reservando a sua posição definitiva no que diz respeito às respectivas situações da Republica Popular da China e do Estado de Taiwan, decisão que depende principalmente de uma determinação precisa do estatuto internacional destas duas entidades, autoriza os atletas tanto de uma como de outra de acordo com o Comité Organizador dos Jogos Olímpicos de Helsínquia a participarem nas provas da Olimpíada actual nas modalidades desportivas em que as respectivas Federações Internacionais tenham admitido as suas inscrições." xxxii

Aprovada a solução, Brundage apressou-se a afirmar que havia de ficar claro que:
"A permissão de participar não implicava o reconhecimento do CON da China Vermelha" e que a atitude do COI "tinha de ser entendida como uma excepção e não como um precedente" Lennartz, Karl (1995:60).27

Na realidade, segundo a Carta Olímpica, só podiam competir nos Jogos atletas que pertencessem a um CON reconhecido pelo COI.

De acordo com Liang Lijuanxxxiii, a comitiva da RPC, liderada por Ron Gaotang (1912-2006) xxxiv secretário da Liga da Juventude, era composta por quarenta elementos que iriam participar no futebol, no basquetebol e na natação. Infelizmente, a comitiva chegou atrasada pelo que só um nadador de seu nome Wu Chuanyu, participou nas provas de qualificação, mas foi eliminado. Contudo, para os chineses, "fazer içar a bandeira vermelha das cinco estrelas da nova China nos Jogos Olímpicos já era uma vitória" Liang, Lijuan (2007:26) ${ }^{32}$, na medida em que havia elementos no COI que se opunham à participação da RPC nos Jogos. E opunham-se de tal maneira que o convite para a RPC só tinha sido enviado quando os Jogos já tinham começado.

\section{O Regresso do Prof. Shou Yi Tung}

Dos encontros havidos com a delegação da RPC, o Presidente Edström tomou conhecimento de que o Prof. Shou Yi Tung, membro do Comité Olímpico Internacional, com quem tinha tentado entrar em contacto depois da fundação da RPC, afinal, estava vivo e vivia em Pequim. Para todos os efeitos, ele continuava a ser o Embaixador do COI para a RPC. Em conformidade, Edström pediu aos representantes da RPC para que o Prof. Shou Yi Tung se deslocasse imediatamente a Helsínquia.

O Prof. Shou Yi Tung acabou por chegar a Helsínquia a 2 de Agosto, a tempo de participar na última reunião da Comissão Executiva do COI. Porém, o Prof. Shou Yi Tung não chegou sozinho mas acompanhado de um intérprete, que dizia que o Prof. Shou Yi Tung somente falava chinês. $\mathrm{O}$ intérprete era nem mais nem menos do que He Zhenliang que mais tarde viria a ser Presidente do Comité Olímpico Chinês, membro da Comissão Executiva do COI, Vice-presidente do COI e responsável pelas candidaturas de Pequim à organização dos Jogos Olímpicos. Ao tempo, Zhenliang iniciava a sua carreira no domínio 
do Movimento Olímpico, precisamente naquela reunião. Liang, Lijuan (2007:41) ${ }^{32}$ Porquê He Zhenliang? Porque segundo Xu Guoqi (2008)26 à falta de outra organização, as autoridades de Pequim serviram-se da Liga Comunista da Juventude da qual He Zhenliang fazia parte, para acompanhar a equipa da RPC a Helsínquia.

O currículo do Prof. Shou Yi Tung era suficientemente expressivo para causar pelo menos algumas preocupações às autoridades da RPC. Por isso, somos levados a especular, que as autoridades chinesas não se podiam permitir colocar nas mãos de alguém conotado com o antigo regime e com uma currículo americanizado, os destinos da RPC no Movimento Olímpico internacional, muito embora, posteriormente, o Prof. Shou Yi Tung passasse a ser no interior do COI, como alguém que tinha aderido às fileiras de Mao Zedong.xxxv

He Zhenliang, com pouco mais de vinte anos, iniciou a sua actividade no domínio do Movimento Olímpico, enquanto intérprete, mas, o que ele era de facto, era um quadro do partido encarregue de defender as decisões do seu governo junto do COI. Relativamente à presença de Zhenliang enquanto tradutor, Liang, Lijuan afirma:

"Zhenliang podia ser seu tradutor (do Prof. Shou Yi Tung), e se acontecesse qualquer coisa inesperada os dois podiamna discutir entre eles." Liang, Lijuan (2007:41). ${ }^{32}$ O problema é que o Presidente do COI Edström sabia que o Prof. Shou Yi Tung falava inglês, já que tinha estudado nos EUA e tinha trabalhado durante muitos anos para o YMCA na China. Quanto à justificação de Zhenliang poder ter qualquer opinião sobre qualquer assunto tratado, é no mínimo ingénua, na medida em que, ao tempo, Zhenliang era um jovem de 22 anos completamente ignorante em assuntos desportivos e, ainda mais, em assuntos do foro do Olimpismo.

Irritado com a situação, Edström pediu ao Prof. Shou Yi Tung e ao intérprete para abandonarem a sala.xxxvi A propósito deste incidente segundo a versão de Brundage (1973), 30 o Prof. Shou Yi Tung apareceu numa Sessão do COI acompanhado por dois compatriotas. O Presidente do COI, Sigfrid Edström, saudou o Prof. Shou Yi Tung, perguntando-lhe de seguida quem eram os seus companheiros?

Imediatamente um deles informou que eram intér- pretes, na medida em que o Prof. Shou Yi Tung não falava nem francês, nem inglês. Depois, Edström informou os acompanhantes do Prof. Shou Yi Tung que a Sessão do COI era restrita aos seus membros, pelo que lhes pedia para saírem. E saíram os três. Efectivamente, só o Prof. Shou Yi Tung era membro do COI com plenos direitos a participar na reunião. Esta situação foi muito penosa para os chineses, na medida em que o próprio Primeiro-ministro Zhou Enlai tinha recebido os líderes da comitiva antes deles partirem para Helsínquia, recomendando-lhes que se deviam opor à existência no COI de "duas Chinas". Mas mais, Zhou Enlai instruiu a delegação para fazerem todos os possíveis para travarem os objectivos de T. C. Wang, um dos membros chineses no COI que se tinha retirado para Hon Kong. Liang, Lijuan (2007:41) ${ }^{32}$ Quer dizer que a situação de Taiwan era uma obsessão para os líderes chineses que se serviam do desporto para a combaterem. Apesar deste catastrófico encontro, por pressão da URSS sobre o COI, a RPC acabou por participar nos Jogos da XV Olimpíada. Entenda-se que a pressão da União Soviética sobre o COI, não teve outra intenção senão a de obter vantagem competitiva no âmbito da política internacional. Na realidade, a URSS tinha aderido ao COI em 1950, pelo que era de seu interesse reforçar o bloco comunista dentro da organização. Nos Jogos de Helsínquia a URSS obteve resultados extraordinários que espantaram o mundo do desporto. Brundage, completamente enganado, congratulou-se com o facto, dizendo convictamente que era uma vitória do Olimpismo na medida em que fazia cair a "cortina de ferro" que separava a URSS do resto do mundo. Mal sabia Brundage que o interesse da URSS pouco ou nada tinha a ver com a promoção do Olimpismo, mas tão-somente com a propaganda do regime soviético e a superioridade do sistema comunista. E o primeiro resultado conseguido pela URSS, ao forçar a entrada da RPC nos Jogos Olímpicos, foi o afastamento por iniciativa própria da delegação do regime nacionalista (Taiwan) que em protesto pela participação da RPC acabou por se retirar dos Jogos. Claro que esta retirada representou também uma derrota para os EUA. Depois, as autoridades de Taiwan promoveram um blackout total na comunicação social relativamente a qualquer notícia acerca do Jogos Olímpicos de Helsínquia (1952). 
Ainda segundo Xu Guoqi (2008), ${ }^{26}$ a URSS ao forçar a entrada da RPC conseguiu antecipar o problema das "duas Chinas", obrigando o COI a tratar de um assunto que não estava minimamente preparado para o fazer. Vivia-se já em plena guerra-fria e o Movimento Olímpico era um excelente local para se esgrimirem argumentos ideológicos, através da competição desportiva.

\section{Reconhecimento do CON-Pequim}

O Prof. Shou Yi Tung acabou por aparecer sozinho na $50^{\text {a }}$ Sessão do COI realizada de 10 a 15 de Maio em Atenas. Contudo, a situação desencadeada pela existência de "duas Chinas" no seio do COI não era fácil de resolver:

- Levantar problemas ao CON-Taiwan era ir contra o regime de Chiang Kai-shek protegido dos EUA;

- Não reconhecer o CON-Pequim era não reconhecer o $\mathrm{CON}$ do país mais populoso do mundo mas, em contrapartida, era reconhecer o CON de um país que não pertencia à $\mathrm{ONU}$;

- Reconhecer os dois CONs era ir contra a Carta Olímpica que só aceitava um CON por país.

Então, depois de um longo debate, o CON-Pequim, quer dizer, da China Popular, foi reconhecido pelo COI, numa votação que 23 a favor, 21 contra.

Segundo o COI, uma das razões porque o CON da RPC levou tanto tempo a ser reconhecido, ficou-se a dever ao facto de se fazer representar por políticos "cheios de legalidades" e não por desportistas.xxxvii Ora, isto só revela que todo o processo estava contaminado e por todos os lados, por questões de ordem política.

A partir de então, para além do CON-Taiwan da China Nacionalista, com sede em Taipé, passou a existir também um CON-Pequim da China Popular. Segundo o COI, ambos os CONs estavam em condições de participar nos próximos Jogos Olímpicos a realizar em Melbourne (1956) na Austrália.

Aparentemente parecia que tudo estava resolvido. O problema é que a procissão ainda ia no adro.

\section{Duas Chinas dois Comités Olímpicos}

Segundo Otto Schantz (1995), xxxviii em 1955, o CONTaiwan reivindicou ser o único representante da China no Movimento Olímpico. Como não podia deixar de ser, o CON-Pequim tinha de reagir. Em conformidade, o Prof. Shou Yi Tung, na $51^{\text {a }}$ Sessão do COI que se realizou de 13 a 18 de Junho de 1955 em Paris, levantou a questão de Taiwan ser parte integrante da China, pelo que o desporto naquela ilha devia estar subordinado ao CON-Pequim. Em consequência, pedia a exclusão do CON-Taiwan do COI.

Avery Brundage, ao tempo já Presidente do COI, segundo as suas próprias memórias, ${ }^{26}$ informou os chineses da RPC que o problema das "duas Chinas" era um problema político que não competia ao COI resolver. Para Pequim o problema das "duas Chinas" era uma questão crucial ao ponto dos dirigentes da RPC colocarem as relações com o COI ao mesmo nível das relações com a ONU. Segundo o site do COC, xxxix em Junho de 1955, Rong Gaotang, VicePresidente e Secretario-Geral do CON-Pequim, defendeu numa reunião da Comissão Executiva do COI que:

"A aceitação do Comité Olímpico de Taiwan pelo COI era ilegal e violava o espírito da Carta Olímpica" (...) "o COI devia desistir do seu reconhecimento." 46

Brundage, não aceitou as pretensões do CONPequim, dizendo aquilo que ele, contra toda a evidência, mais gostava de dizer:

"O desporto nada tem a ver com a política."

Brundage, ao instituir nesta perspectiva acéfala de abordar as questões políticas no seio do COI, originou uma das maiores confusões de que há memória no Movimento Olímpico. Segundo os chineses, Brundage jogava com truques políticos sujos (dirty political tricks), na medida em que, debaixo do discurso apolítico, defendia os seus próprios interesses e os interesses dos EUA. Em consequência, o CONTaiwan continuou a coexistir com o CON-Pequim da China Popular.

Em conclusão, o que aconteceu na $51^{\text {a }}$ Sessão do COI foi uma estrondosa derrota da RPC, ao ponto da comitiva chinesa, de volta Pequim, ter sido criticada pelo próprio Primeiro-ministro Zhou Enlai.

Entretanto, as relações entre o Prof. Shou Yi Tung e Avery Brundage começaram a aquecer.

\section{Jogos de Melbourne (1956)}

Aquando da preparação dos Jogos da XVI Olimpíada - Melbourne (1956), o CON-Pequim escreveu uma carta aos trabalhadores e desportistas da "província de Taiwan" a fim de os convidar a participar nos 
campeonatos a realizar em Pequim, que seleccionariam uma única equipa chinesa que participaria nos Jogos de Melbourne. Também foi garantido aos chineses de Taiwan que, uma vez concluídas as provas de selecção em Pequim, eles seriam livres de regressar a Taiwan. É evidente que os chineses de Taiwan nem se deram ao trabalho de recusar tal convite. Em consequência, segundo Brundage, quando os Jogos de Melbourne (1956) estavam prestes a começar, os dirigentes do Comité Olímpico da República Popular da China informaram o COI que não participariam caso os "bandidos de Taiwan" participassem. ${ }^{38}$ Segundo o relato de Brundage (1973:261)26 as coisas passaram-se assim:

"À minha chegada a Melbourne para os Jogos, os dirigentes do Comité Olímpico de Pequim pediram-me uma entrevista. Desejavam saber se ia chegar uma delegação da Formosa. Disseram-me que tinham preparado uma equipa de 150 de homens e mulheres que aguardavam em Pequim, mas que não iriam aos Jogos caso viessem "os bandidos de Taiwan". Brundage, respondeu-lhes com o discurso do costume: "Não eram os países que competiam mas os atletas pelo que o reconhecimento de um CON não significava necessariamente o reconhecimento do governo do país."

Como os dois comités eram reconhecidos pelo COI, ambas as delegações podiam participar.

Entretanto, o Prof. Shou Yi Tung fez os maiores esforços para explicar a Brundage a situação de Taiwan no quadro histórico da China. No entanto, o Presidente do COI manteve-se na sua, considerando a existência de "duas Chinas", o que a RPC se recusava a aceitar. Para além do mais, apesar dos repetidos protestos do CON de Pequim, o COI insistia em utilizar nos seus documentos "Pequim - China" e "Formosa-China" o que para além de sugerir a existência de "duas Chinas" colocava as duas realidades políticas em igualdade de circunstâncias, coisa que a RPC discordava.

Brundage recusou-se a admitir qualquer argumento, pelo que o COI acabou por confirmar que reconhecia dois CONs de "duas Chinas": CON-Pequim e CONTaiwan. O "reconhecimento" implícito da existência de "duas Chinas" foi também assumido por diversas Federações Internacionais o que era inaceitável para a RPC. Em consequência, a RPC decidiu não participar nos Jogos de Melbourne.
Avery Brundage, nas suas memórias, conta ainda que, na cerimónia de boas vindas à delegação de Taiwan, pronunciaram-se os habituais discursos, a banda tocou o hino nacional e içou-se a bandeira. Mas, quando o responsável australiano se preparava para içar a bandeira da China Nacionalista, um chinês vindo não se sabe de onde, chegou-se ao pé do australiano e disse-lhe que a bandeira da China não era aquela. $\mathrm{O}$ australiano foi imediatamente trocar a bandeira. O problema é que trocou a bandeira da China Nacionalista (Taiwan) pela bandeira da China Popular (Pequim). E a bandeira da China Popular foi içada perante os olhos incrédulos da delegação da China Nacionalista. Após a cerimónia, claro que a bandeira foi rapidamente arreada e novamente substituída. Claro que, o solícito chinês desapareceu tal como tinha aparecido. Estórias da guerra-fria.

\section{Ruptura e isolamento}

A 19 de Agosto de 1958, em plena crise do Estreito da Formosa, a RPC anunciou retirar-se do Movimento Olímpico. Depois, a 25 de Agosto de 1958 foi recebido na chancelaria do COI em Lausanne um comunicado oficial a confirmar a situação.xl A fim do abandono do COI não poder vir a ser considerado uma questão pessoal contra Brundage, a RPC retirou-se simultaneamente de várias organizações desportivas internacionais, optando por uma política de isolamento desportivo. Assim, abandonou as Federações Internacionais de Atletismo, Basquetebol, Futebol, Luta, Pesos e Halteres, Natação, Tiro e Ténis.

A retirada da RPC deixou o COI bastante perturbado de tal maneira que, a "Olympic Review" no 64 de Novembro de 1958, acusava a RPC de ter optado por um "isolamento esplêndido", perguntando-se simultaneamente as razões de tal atitude?

O que é facto é que a RPC, abandonou o COI acusando Brundage de ser um "agente imperialista dos EUA". E o Prof. Shou Yi Tung escreveu ao COI: "Brundage, Presidente do Comité Olímpico Internacional violou deliberadamente a Carta Olímpica com o fim de servir o projecto imperialista dos Estados Unidos de criar "duas Chinas". Declaro formalmente que recuso cooperar com ele ou de ter quaisquer relações com o COI enquanto esta organização estiver sob o seu domínio." $\mathrm{Na}$ carta resposta que Brundage escreveu ao Prof. 
Shou Yi Tung, argumentou que Taiwan não pertencia à China e que os nativos de Taiwan não eram nem chineses nem japoneses. Mas, como argumentava o Prof. Shou Yi Tung desde os tempos mais remotos que Taiwan era território chinês. Tinha, de facto, estado debaixo da ocupação Japonesa de 1895 a 1945, mas, depois da II Guerra Mundial, de acordo com a Declaração do Cairoxli e a Declaração de Potsdamxlii, foi restituída à China.

Mas o que mais perturbou Brundage foi o facto da RPC ter afirmado que não voltaria ao COI enquanto Brundage fosse o seu líder. E cumpriu.

Mesmo relativamente à URSS, a RPC optou por um corte de relações. Aliás, nos anos sessenta desenrolou-se um conflito aberto entre a RPC e a URSS, pelo que o corte das relações desportivas vinha mesmo a calhar.

Entretanto, em meados dos anos sessenta, a RPC entrou em plena Revolução Cultural pelo que as relações desportivas internacionais ficaram reduzidas aos países em vias de desenvolvimento. Em consequência, o Movimento Desportivo na RPC sofreu um enorme retrocesso e os maiores atentados à dignidade não só dos desportistas como do próprios dirigentes.

A ruptura da RPC com o COI, tendo em atenção a ideia de Michel Bouet (1968), xliii caracterizou-se por ser do tipo de conflito que dissimula por detrás dele um outro mais importante e mais grave.

Efectivamente, a RPC utilizou o desporto para dissimular um conflito muito mais grave e importante para as autoridades chinesas que era o das "duas Chinas", que, no fundo, representava duas concepções do mundo radicalmente opostas. A partir de então, o COI que dizia não ser uma organização política, passou a estar no centro das questões políticas entre dois sistemas que se digladiavam: o sistema capitalista e o sistema comunista.

A entrada da RPC no COI processou-se com enormes dificuldades na medida em que estavam em confronto duas ideologias fechadas, a do COI e a da RPC, que se julgavam a salvação do mundo. Cada uma delas tentou impor à outra as suas ideias e os seus objectivos sem fazer o mínimo esforço para compreender as ideias e os objectivos da parte contrária. Portanto, as confusões e a ignorância de parte a parte, os mal entendidos e o sacrifício de pessoas como o Prof. Shou Yi Tung, acabaram por dificultar a normal resolução de um problema em que todos falavam mas ninguém se ouvia. Tudo acabou ingloriamente na ruptura e no isolamento desportivo da RPC que, posteriormente, como vamos ver, conduziu a situações degradantes no Movimento Desportivo mundial.

\section{ESTRATÉGIA ALTERNATIVA DA RPC}

Apesar de tudo lhe ter corrido mal, a RPC não se podia deixar isolar completamente da cena desportiva internacional, pelo que decidiu começar a jogar noutros tabuleiros políticos. Nesta conformidade, conseguiu que nos IV Jogos Asiáticos (1962), a Indonésia enquanto país organizador impedisse Taiwan de participar. O próprio Primeiro-ministro Zhou Enlai meteu-se no assunto. O que aconteceu foi que a RPC conseguiu manobrar nos bastidores de modo a que a República da China (Taiwan) não participasse nos IV Jogos Asiáticos porque os vistos de entrada na Indonésia nunca lhes chegaram às mãos. Assim, a Indonésia salvava a face e a RPC tinha aquilo que mais queria que era afastar Taiwan dos Jogos Asiáticos. Como se vê, em matéria de utilização do desporto pela política, a RPC nunca "brincou em serviço". xliv

Perante esta situação, algumas organizações internacionais decidiram não reconhecer os Jogos Asiáticos e deixaram de reconhecer o Comité Olímpico da Indonésia. Para além do mais, a Indonésia foi proibida de participar nos Jogos Olímpicos. Em resposta, o Presidente da Indonésia Sukarno (1901-1970) propôs a institucionalização dos Jogos das Novas Potências Emergentes. Estes Jogos realizaram-se em Jakarta em Setembro de 1963 e em 1966 em Phnom Penh. Ora, os Jogos das Novas Potências Emergentes serviram sobretudo para demonstrarem a força do Terceiro mundo no Movimento Desportivo internacional, que pretendia substituir-se ao próprio Movimento Olímpico.

\section{Primeiro a amizade, depois a competição}

A partir da institucionalização da RPC e a consequente organização social, a perspectiva belicista, chauvinista e hiper competitiva de Mao Zedong que ele próprio expressou no livro "Um Estudo de Educação Física” a que já nos referimos, não se adaptava aos novos tempos da revolução comunista. 
Na realidade, a visão que Mao expressou no seu livro, tinha a ver com tudo menos com uma visão marxista da organização politica e social que se devia também projectar nas práticas desportivas. Assim, na fase de isolamento da RPC, o desporto foi colocado ao serviço dos superiores interesses da política externa, mas numa perspectiva completamente diferente da preconizada por Mao em 1917. Já não se tratava simplesmente da preparação para a guerra ou sequer simplesmente vencer os jogos e os campeonatos. As relações entre os povos passaram a ser a palavra de ordem do desporto na RPC. E o desporto passou a ser um poderoso instrumento da construção daquela amizade. Em consequência, a amizade sobrepôs-se à lógica da vitória que deve presidir a toda e qualquer competição desportiva. No entanto, a máxima adoptada pelo desporto chinês não deixava margem para dúvidas:

"A amizade é eterna, a vitória passageira."

A partir de então, na RPC os jogos passaram a ser disputados sem árbitros, na medida em que o resultado era o que menos interessava. O sistema ideológico da RPC fundamentava-se na construção de uma rede de solidariedade em que o modelo de competição desportiva era pura e simplesmente desprezado. Assim, nos anos cinquenta as autoridades chinesas começaram a impor aquilo a que John Hoberman (1984:219) xlv designou por uma visão "maoísta ortodoxa" que sobreviveu até 1976, quer dizer, até ao fim da Revolução Cultural. Esta visão, baseava-se fundamentalmente na construção de uma rede de relações humanas à margem dos modelos construídos na base da promoção da performance humana. Assim, o modelo maoísta, inspirado no modelo dos primeiros tempos da URSS, assentava em três pilares fundamentais:

- A educação física;

- O desporto;

- A condição física.

O que interessava era promover a educação física, o desporto recreativo e a saúde das populações. Os programas desenvolvidos, segundo Hoberman, foram inspirados na máxima do desporto Soviético dos anos trinta que dizia "prontos para o trabalho e para a defesa". Contudo, nos anos cinquenta, quando a China aderiu ao programa da URSS, já esta tinha abandonado a visão de um "desporto não competiti- vo", na medida em que tinha decididamente aderido ao Movimento Olímpico.

A visão Maoísta ortodoxa, à semelhança daquilo que tinha acontecido na URSS era muito mais marcada pela ideologia do que pela performances desportivas. A competição era desvalorizada. O objectivo era contrariar os sentimentos agressivos entre competidores que caracterizavam a prática desportiva burguesa. Conforme refere Huang Yaling,xlvi da Universidade do Desporto de Pequim, durante a Revolução Cultural o desporto devia ser jogado pelo simples prazer de jogar, sem quaisquer preocupações competitivas. De alguma maneira, foi com este espírito que a RPC participou nos Jogos das Novas Potências Emergentes - África, Ásia e América Latina. ${ }^{1 v i i}$

\section{Jogos das novas potências emergentes}

Os primeiros Jogos das Novas Potências Emergentes realizaram-se em Novembro de 1963 em Jacarta. A RPC atribuía-lhes grande importância, ao ponto da comitiva chinesa ter sido recebida pelo Primeiroministro Zhou Enlai, que a alertou para a necessidade de se reforçar a unidade entre os países de África, Ásia e América Latina. Nesta conformidade, a comitiva da RPC devia ser portadora de um espírito propiciador do desenvolvimento de uma nova atmosfera política entre as nações envolvidas. Para Zhou Enlai, não se tratava de competir numa perspectiva Ocidental em que os atletas se consideravam uns aos outros como rivais, mas de promover a amizade mútua através do desporto. E Zhou Enlai até deu o mote que devia animar a comitiva da RPC:

"Unidade contra o imperialismo, consulta democrática, aprender com os outros e elevação comum." Liang, Lijuan (2007:85). 32

Mas Zhou Enlai foi ainda mais longe. De facto, o Primeiro-ministro chinês recomendou à comitiva para:

"Ajudar a equipa da Indonésia a conseguir bons resultados na medida em que era um país fundador dos Jogos das Novas Potências Emergentes e, simultaneamente, organizador dos primeiros Jogos. O badminton era uma modalidade muito popular na Indonésia pelo que o país tinha altas perspectivas de ganhar a medalha de ouro." (Liang, Lijuan, 2007:85-86).32

O problema é que, ao tempo, a China no badminton era possuidora de atletas de alto gabarito. E como os 
atletas chineses tinham estado fora das competições mundiais durante bastante tempo, estavam desejosos de mostrar a sua força. Por isso, o Vice-primeiroministro Chen YI disse:

"Considerem os sentimentos do país organizador e deixem a Indonésia ganhar algumas medalhas em badminton, quando regressarem a casa tratarei de vocês." (Liang, Lijuan, 2007:86). 32

Entretanto, He Dong também Vice-primeiro-ministro contrapôs:

"Há muito que não competimos no estrangeiro, devemos mostrar ao mundo os nossos progressos no desporto. Se ganharem todas as medalhas em badminton, quando regressarem a casa tratarei de vocês." (Liang, Lijuan,

2007:85). 32

Zhou Enlai riu-se e disse:

"Prestem igual atenção à amizade e à performance desporti$v a$, desenvolvam o vosso potencial em ambos." (Liang, Lijuan, 2007:85). ${ }^{32}$

O Vice-primeiro Ministro He Long acompanhou a equipa chinesa a Jacarta pelo que assistiu in loco toda a competição. Contudo, quando se apercebeu que os chineses iam ganhar tudo, e do prejuízo que esse facto podia significar para as relações entre a China e a Indonésia, ordenou que deixassem a Indonésia ganhar a medalha de ouro. Claro que o atleta chinês fez por perder o jogo enquanto que a televisão indonésia comentava que parecia que o chinês, de um momento para o outro, tinha deixado de saber jogar. (Liang, Lijuan, 2007:87).32

Lijuan Liang a propósito comentou:

"Nesta perspectiva, podemos ver que embora He Long - o

Vice-primeiro-ministro - tivesse uma personalidade caracterizada por gostar de ganhar, ele tinha dos assuntos uma perspectiva dos altos interesses políticos. Os indonésios tiveram um entendimento tácito do jogo e ficaram muito agradecidos à China." (Liang, Lijuan, 2007:87).32

E Zhou Enlai enviou um telegrama de felicitações com os seguintes dizeres:

"A inauguração dos Jogos das Novas Potências Emergentes marcam uma grande vitória conquistada pelo povo das novas nações emergentes, na sua luta contra o controlo e o monopólio sobre o desporto internacional pelo imperialismo e o velho e novo imperialismo." (Liang, Lijuan, 2007:87).32

De facto, toda a missão tinha sido acompanhada pelo Primeiro-ministro Zhou Enlai e não era para menos. O interesse dos chineses era tal que, mesmo numa situação de grandes dificuldades económicas, pagaram a participação nos Jogos das Novas Potências Emergentes aos países que não podiam suportar as despesas.

Pelo seu lado, o COI, liderado por Avery Brundage, ameaçava excluir da participação nos Jogos Olímpicos, pelo período de 12 meses, todos os atletas que participassem nos Jogos das Novas Potências Emergentes.xvivii A Indonésia e a Coreia do Norte foram admitidas à participação nos Jogos Olímpicos de 1964 realizados em Tóquio, na condição de nenhum dos seus atletas ter participado nos Jogos das Novas Potências Emergentes. Mesmo assim, os países visados enviaram para Tóquio atletas que tinham competido nos Jogos das Novas Potencias Emergentes na expectativa de poder haver uma mudança de atitude por parte do COI. Todavia, o COI foi intransigente e não mudou de posição. A Coreia do Norte acabou por retirar a totalidade da sua equipa. (Liang, Lijuan, 2007:97). ${ }^{32}$ Quer dizer, os atletas foram apanhados no fogo cruzado da guerra-fria.

A interpretação que se pode fazer é a de que havia da parte do COI e em especial de Avery Brundage uma séria intenção política de isolar a RPC. Como Brundage não podia atacar directamente os países, resolveu de uma forma a todos os títulos reprovável penalizar os atletas, perante a indiferença da generalidade do Movimento Desportivo.

Avery Brundage sempre manifestou uma profunda hipocrisia nas disputas no interior do COI relativamente ao problema das "duas Chinas". Por um lado, afirmava que o COI não se podia imiscuir em questões políticas, mas, por outro, era ele que se utilizava politicamente do COI em defesa dos seus próprios interesses e também dos interesses dos EUA. Note-se que as relações entre EUA e China haviam sido cortadas em Outubro de 1949 quando forças comunistas lideradas por Mao Zedong depuseram o governo nacionalista do general Chiang Kai-shek. Na perspectiva política da RPC, a continuação dos Jogos da Novas Potências Emergentes era uma questão crucial. Assim, Zhou Enlai voltou a envolver-se no processo quando soube que o Egipto exigia uma soma considerável para organizar os II Jogos. E faziao com a convicção do conhecimento que tinha de 
que a RPC havia auxiliado a Argélia com um subsídio substancial para construir o centro de conferências que serviu para a realização da II ${ }^{\mathrm{a}}$ conferência África-Ásia, realizada em 1965. (Liang, Lijuan, 2007:98).32 Muito embora o investimento não tenha sido realizado, podemos simplesmente concluir que se a China teve aquela atitude estratégica em defesa dos seus interesses no mundo, num tempo de grandes dificuldades económicas, o que é que ela hoje não fará em defesa dos seus interesses estratégicos, com a capacidade financeira de que é possuidora.xlix

\section{Campeonato do Mundo de Ténis de Mesa - 1971}

Em 1971 o Campeonato do Mundo de Ténis de Mesa decorreu no Japão em Nagoya. A Coreia do Norte não queria participar na medida em que existia no Japão uma comunidade 600 mil norte-coreanos que, perante os previsíveis fracos resultados desportivos, podia demonstrar alguma hostilidade para com o regime de Pyongyang. Em consequência, as autoridades da Coreia do Norte entenderam não participar. Contudo, aos chineses interessava-lhes que a Coreia do Norte também participasse. Então, como refere Xu Guoqi (2008), 30 através da intervenção directa de Zhou Enlai, os norte-coreanos foram convencidos a participar a troco de algumas vitórias com que impressionariam os concidadãos que viviam no Japão.

O problema foi que aconteceu um imponderável. A comitiva chinesa era liderada por Zhao Zhenghong um militar que não esteve pelos ajustes políticos. Para ele, o desporto tal como a guerra era para ganhar. Em consequência, a equipa da China que, apesar dos efeitos negativos da Revolução Cultural, tinha os melhores jogadores do mundo, acabou por derrotar a Coreia do Norte por 3-0 impedindo-a de ganhar os homens singulares como estava previsto. Quanto ao Japão, todos os atletas chineses derrotaram os atletas japoneses.

O segundo problema surgiu quando a comitiva chinesa regressou a casa. Aquilo que aconteceria em qualquer outro país do mundo, na China aconteceu precisamente o contrário. A equipa foi chamada a Zhou Enlai que obrigou o chefe da comitiva Zhao Zhenghong a fazer um relatório autocrítico e, depois, mandou-o ir à Coreia do Norte pedir desculpas. Zhao apresentou directamente desculpas ao Presidente nortecoreano Kim II Sung. O próprio
Zhou Enlai, não deixou também de se desculpar perante os norte-coreanos pelo comportamento da equipa chinesa. Depois, Kim II Sung teve a oportunidade de agradecer aos camaradas Mao e Zhou os esforços realizados para reforçarem a amizade entre a China e a Coreia do Norte.

\section{Aprender à própria custa - competição é competição} Os chineses, ainda segundo Xu Guoqi (2008), ${ }^{30}$ haviam de aprender à sua custa. No apuramento do futebol para os Jogos de Moscovo (1980), os chineses e os norte-coreanos voltaram a combinar o resultado. Para que todos ficassem satisfeitos o resultado ajustado foi de 3-3. Mas, quando o resultado atingiu a cifra combinada, os norte-coreanos "roeram a corda", meteram mais um golo e fizeram 4-3.

Depois, puseram-se a jogar à defesa e não deixaram os chineses empatar o jogo como estava combinado. Com esta derrota, os chineses acabaram por concluir que, no domínio da competição desportiva não podem existir resultados de amizade. Competição é competição. Apesar de tudo, uma nova perspectiva de entender a competição quer nacional quer internacional de uma forma séria, só veio a ser posta em prática a seguir à morte de Mao Zedon.

A RPC utilizou o desporto das maneiras mais criticáveis, ao chegar ao ponto das autoridades políticas ao mais alto nível promoverem a corrupção dos resultados em nome de uma solidariedade que, como se viu, não tinha qualquer sentido, na medida em que a contrapartida geralmente não funcionou. Depois, os chineses acabaram por aprender à própria custa que a competição é uma coisa séria que não dá para brincar. Mas o problema mais sério originado pela posição hipócrita de que "primeiro estava a amizade e, depois, a competição", originou que um "modelo de desporto não competitivo", a partir dos anos sessenta, passasse a ter influência em países como a França aonde os neo-marxistas, desanimados com o revisionismo do Partido Comunista Francês promoviam o maoísmo. Ora, esta perspectiva ultrapassou as fronteiras francesas e projectou-se noutros países entre os quais Portugal com incidências nefastas nos programas da disciplina de Educação Física que ainda hoje se fazem sentir e comprometem o desenvolvimento do desporto do país. ${ }^{1}$ 


\section{EXPULSÃO DA REPÚBLICA DA CHINA (TAIWAN) DO COI}

Há muito que a RPC tinha assumido que a sua luta dentro e fora do COI ultrapassava em grande medida os problemas do mundo do desporto. De facto, para a RPC o desporto e o Olimpismo eram instrumentos fundamentais para ser reconhecida pela ONU. Em conformidade, jogava fortemente com os conflitos de interesses internos do próprio COI, uma organização internacional, como todas elas, com muitos paradoxos e contradições.

Na $56^{\text {a }}$ Sessão do COI realizada 23 a 28 de Maio de 1959 em Munique, o problema das "duas Chinas" foi um dos temas da sessão. A partir de uma proposta do Marquês de Exeter (1905-1981), foi decidido por 48-7 retirar o CON-Taiwan que utilizava o nome de Comité Olímpico Nacional Chinês da lista oficial dos comités reconhecidos pelo COI e considerar a sua readmissão caso aceitasse mudar o nome. $\mathrm{O}$ texto da decisão que passou a ser conhecida como a "Decisão de Munique" foi o seguinte:

"O Comité Olímpico Nacional Chinês com sede em Taipé, (Taiwan) será notificado pelo Chanceler do Comité Olímpico Internacional que não pode continuar a ser reconhecido sob aquele nome na medida em que não controla o desporto na China, e o seu nome será retirado da lista oficial. Se for realizada uma candidatura de reconhecimento com um diferente nome, será considerada pelo Comité Olimpico Internacional." li

Em conclusão, aquilo que para todos os efeitos aos olhos do mundo foi decidido, foi que a República da China (Taiwan) tinha sido expulsa do COI.

Esta decisão do COI causou tantos problemas que não se percebe como foi possível Brundage deixar avançar o processo. Quanto a nós, só vemos uma de duas possibilidades:

- Ou a votação (que viria a ser posteriormente contestada) apanhou Brundage completamente distraído; - Ou, pelo contrário, Brundage estava bem consciente do que se estava a passar, só que os seus interesses naquele momento ultrapassavam as posições que tinha assumido no passado.

O problema é que as novas conveniências de Brundage entravam frontalmente em confronto com as dos EUA. Hoje, é legítimo pensar que Brundage enquanto Presidente do COI, dificilmente podia conviver com a situação de ter o CON do país mais populoso do mundo, ao tempo, com cerca de 600 milhões de habitantes, fora do COI. Mas mais. Para Brundage, era certamente muito difícil conviver com o facto das autoridades da RPC terem afirmado solenemente que só regressariam ao COI depois de Brundage sair. Em conformidade, Brundage fez uma jogada de mestre. O que ele, muito provavelmente, desejava era criar as condições para o regresso ao seio do COI da RPC. Afastada Taiwan, a RPC regressaria em grande triunfo e ele faria parte desse triunfo. Entretanto, relativamente a Taiwan era só uma questão dos nacionalistas mudarem de nome o que até já vinha a acontecer noutras organizações internacionais.

O problema é que Brundage não foi capaz de, minimamente, imaginar a reacção de várias entidades norte-americanas, bem como, posteriormente, da generalidade da população norte-americana. Se a nível das entidades as questões se colocavam na dimensão global da guerra-fria, lii no que diz respeito ao povo americano a imagem que passou foi a de uma Taiwan protegida dos EUA, a ser trucidada pelos interesses da enorme China comunista. Em consequência, Brundage deve ter passado um dos períodos mais difíceis da sua vida, na medida em que, para além de aos olhos dos americanos, ter posto em causa os interesses do seu próprio país, teve, por diversas vezes, de ouvir aquilo que não queria e de contradizer aquilo que tinha sido decidido pelo COI. Para alguém com uma personalidade mais ou menos autocrática como era a de Brundage, não deve ter sido mesmo nada fácil.

\section{Pesadelo de Brundage}

Ao tempo, a ONU ainda não tinha reconhecido a RPC o que só viria a acontecer em finais de 1971. Só Taiwan era reconhecida como República da China na ONU. Por outro lado, a decisão de expulsão relativamente ao Comité Nacional Olímpico da China Taiwan, ia contra tudo aquilo que tinha sido o discurso oficial que afirmava que o desporto nada tinha a ver com a política, e que não eram os países que interessavam mas os atletas. Se o desporto nada tinha a ver com a política, como era possível que o COI, no que diz respeito ao reconhecimento dos países, ultrapassasse a situação existente na $\mathrm{ONU}$, tornando-se, deste modo, um instrumento de pressão no sentido de forçar a entrada da RPC na ONU? Porque, de facto, 
esse era o primeiro objectivo da RPC e o COI, com a sua atitude, estava pura e simplesmente a ser um instrumento político nas mãos da RPC.

Assim, a resolução de Munique, em plena guerrafria, não podia deixar de ter enormes repercussões nos EUA. Brundage e o COI foram acusados de ceder aos países comunistas liderados pela URSS, a fim de facilitarem o regresso da China Popular (Pequim) ao Movimento Olímpico, à custa da exclusão da China Nacionalista (Taiwan). Brundage acabou por ser atacado pelo Governo, pelo Congresso e pelo próprio Presidente Eisenhower. Até a contagem dos votos na Sessão do COI realizada em Munique foi posta em causa e precisamente por um membro americano do COI de seu nome Douglas Roby (1898-1992).

Simultaneamente, a população norte-americana começou a sentir que o significado da expressão guerra-fria afinal não era assim tão fria quanto isso, ao tomar conhecimento dos bombardeamentos efectuados pela RPC às ilhas nacionalistas de Quemoy e Matsu. Em consequência, o embaixador dos EUA nas Nações Unidas, Henry C. Lodge, pediu que a decisão do COI relativamente a Taiwan fosse reconsiderada.

Pelo seu lado, o COA afrontava o COI no sentido de o desafiar a voltar a reconhecer o Comité Olímpico da República da China (China Nacionalista). Para os dirigentes do Comité Olímpico Americano (COA) qualquer atraso na reentrada do Comité Olímpico da República da China prejudicaria seriamente o movimento Olímpico nos EUA. Na realidade, o COA estava de certo modo em pânico na medida em que se encontrava a praticamente um ano da realização dos Jogos Olímpicos de Inverno em Squaw Valley (1960), pelo que não se podia permitir ter um caso que lhe secasse as fontes de financiamento. A questão da expulsão da China Nacionalista do seio do COI estava a pôr em risco os apoios financeiros aos Jogos de Squaw Valley (1960) provenientes dos "sponsors" americanos. Além do mais, muitas entidades exigiam pura e simplesmente a saída do COA do COI o que, ainda pior, comprometia a realização dos próprios Jogos de Squaw Valley.liii

\section{0 dito por não dito}

Perante tal situação, Brundage, pondo de lado todo o seu "horror" a envolver a política no desporto, foi obrigado a entrar em negociações com os chineses de Taiwan, e, desta feita, numa posição de extraordinária debilidade na medida em que estava sem retaguarda. E ao fazê-lo, entrou em contradição com a filosofia do próprio COI que defendia que "só discutia com atletas e não com os governos" ou que "só reconhecia organizações desportivas e não governos", liv conforme esclarecimento prestado pelo COI imediatamente depois da Sessão de Munique. Apesar de tudo, as negociações iniciaram-se, mas como os chineses de Taiwan estavam numa posição favorável, resolveram "esticar a corda" pelo que exigiam ser reconhecidos por Comité Olímpico da República da China. Ora, esta posição seria sempre inaceitável para a RPC.

Perante a situação, Brundage teve de dar o dito por não dito. Assim, começou simplesmente por dizer que a resolução de Munique tinha sido mal interpretada e, a 19 de Julho de 1959, fez a seguinte declaração: "Os termos da resolução adoptado pelo COI na Sessão de 28 de Maio de 1959 (Sessão de Munique) foram infelizes e realmente não expressaram a intenção da Sessão de Munique. A intenção do Comité Olímpico Internacional foi meramente no sentido de identificar os atletas que viviam em Taiwan (Formosa). A Formosa chinesa agora candidatou-se sob o nome do seu país - Comité Olímpico da República da China. Eu recomendarei e apoiarei o reconhecimento deste comité sob este nome."

Apesar de tudo o que Brundage pudesse dizer, aos olhos dos americanos, na Sessão de Munique, a China Nacionalista foi expulsa do COI e a prová-lo está o facto de, conforme a acta da Sessão de Munique, se Taiwan quisesse voltar pertencer ao COI, tinha de desencadear uma nova candidatura.

\section{Jogos Olímpicos de inverno Squaw Valley (1960)}

Em todo este processo a organização dos Jogos Olímpicos de Squaw Valley (1960) teve um papel fundamental. Eram enormes as verbas e os apoios de toda a ordem que estavam em jogo. Em conformidade, a 29 de Junho de 1959, Prentis C. Hale, Presidente da Comissão Executiva dos Jogos, depois de ter tido uma reunião com Avery Brundage, apressou-se, através de uma news release, a informar o público americano:

1 - O Comité Olímpico da República da China (China Nacionalista), foi convidado para participar nos Jogos de Squaw Valley pelo Comité Organizador 
dos VIII Jogos Olímpicos de Inverno; o Comité Olímpico da República da China aceitou e vai ter a oportunidade de aparecer.

2 - O Comité Olímpico da República Democrática da China (China vermelha) não era reconhecido pelo Comité Olímpico Internacional quando o Comité Organizador enviou os convites para participar; presentemente não é reconhecido pelo Comité Olímpico Internacional pelo que não lhe será permitido participar nos Jogos Olímpicos de Inverno de 1960. lvi Simultaneamente, Prentis C. Hale divulgou uma declaração de Brundage, onde este informava os americanos que a decisão do COI de 28 de Maio (Sessão de Munique) teve como único objectivo esclarecer a situação da China Nacionalista no seio da Família Olímpica. Mas dizia mais:

Recentes rumores de que a admissão do Comité Olímpico da China Nacionalista tinha sido negada sob o nome de República da China ou uma variação semelhante não são verdadeiros.lvii

Em todo o processo, Avery Brundage jogou com uma enorme inabilidade e, em consequência, foi apanhado nas malhas das suas próprias contradições. Ao contrário daquilo que ele tinha passado uma vida a afirmar, o desporto e o Olimpismo tinham mesmo a ver com a política. Como Brundage afirmava o contrário, acabou simplesmente por andar a reboque da política, para tentar-se salvar dos problemas que ele próprio tinha desencadeado.

\section{Última Jogada de Brundage}

Se os chineses se utilizaram do desporto para fins políticos, o COI fundamentalmente sob a liderança de Brundage, também não o deixou de fazer.

Brundage nunca permitiu que a questão das "duas Chinas" fosse tratada de uma forma clara, aberta e sem quaisquer preconceitos. A dois anos de abandonar o COI, o que viria a acontecer imediatamente a seguir aos Jogos de Munique (1972), Brundage já com 83 anos de idade continuava a exercer o seu poder autocrático que no final da sua vida já só tina a ver com o seu maior ódio de estimação, quer dizer a RPC. Assim, na 70 ${ }^{\text {a }}$ Sessão do COI realizada de 12 a 16 de Maio de 1970 em Amesterdão, Brundage forçou votação no COI de um novo membro, desta feita Henry Hsu da República da China (Taiwan). lviii Ora, tal proposta, independentemente da sua bondade, só podia provocar mal-estar nos dirigentes da RPC e fazer com que a sua atitude se radicalizasse ainda mais do que já estava. Quer dizer que, ao cabo de 18 anos de incapacidade absoluta para resolver um problema, Brundage com tal atitude pretendeu, pelo menos aparentemente, condicionar a resolução do problema das "duas Chinas" para além da sua liderança no COI.

Henry Hsu foi muito provavelmente, no que diz respeito às "duas Chinas", a última jogada de Samaranch. Todavia, a jogada não revelou ser de grande utilidade na medida em que Henry Hsu, posteriormente, acabou por ser um elemento construtivo na resolução do problema das "duas Chinas". Entretanto eram os próprios membros do COI que ultrapassavam a casmurrice de Brundage. Por exemplo, vários dirigentes do COI tais como Reginald Alexander do Quénia e Giulio Onesti de Itália, visitaram por sua conta e risco a RPC contactando com os dirigentes desportivos chineses. Porém, estas visitas foram mantidas fora do conhecimento de Brundage, na medida em que se sabia que a posição do Presidente do COI seria sempre de oposição porque essa era a posição dos EUA que, ao tempo, não reconheciam a RPC. No entanto, independentemente da vontade de Brundage ou até mesmo dos EUA, a pressão para que as relações entre o COI e a RPC voltassem ao normal há muito que vinham a ser exercidas pelos mais diversos protagonistas.

\section{Conclusão}

Brundage jogou com a questão das "duas Chinas como muito bem entendeu. Apesar desta sua atitude, não se percebe muito bem como é que na Sessão de Munique se deixou cair na situação em que, em termos práticos o CON de Taiwan acabou expulso do COI só podendo regressar se aceitasse mudar de nome. Depois, quando a situação aqueceu, Brundage teve um comportamento errático e incoerente relativamente às suas posições anteriores. Acabou por passar um mau bocado, teve de dar o dito por não dito, a fim de salvar a sua posição que estava a ser muito difícil pela aproximação dos Jogos Olímpicos de Inverno de Squaw Valley (1960). Mas, apesar de todos os seus fracassos, Brundage continuou igual a si próprio. Numa a atitude de pouco respeito pelos elementos do COI e numa provocação descarada 
relativamente à RPC, fez eleger Henry Hsu de Taiwan para elemento do COI. Pelo seu lado, à revelia do próprio Brundage, alguns elementos do COI começaram a estabelecer relações com a RPC. Com a sua longevidade à frente do COI Brundage acabou por, mais uma vez, provar que as lideranças autocráticas acabam geralmente no caos.

\section{REGRESSO AO MOVIMENTO OLÍMPICO}

Não fazia qualquer sentido que a RPC, o país mais populoso do mundo, estivesse fora do Movimento Olímpico. Em conformidade, o mundo comunista fundamentalmente através da URSS, começou a pressionar o COI no sentido deste criar as condições para que a RPC regressasse ao Movimento Olímpico. Mas a pressão sobre o COI não foi só exercida pelo mundo comunista, na medida em que na $56^{\text {a }}$ Sessão do COI, realizada em Munique, ela surgiu dentro do próprio COI. O que aconteceu foi que a RPC recebeu um apoio fundamental para a sua causa do Presidente da International Amateur Athletic Federation (IAAF), David George Brownlow Cecil (1905-1981), o $6^{\circ}$ Marquês de Exeter.lix

Exeter tinha um currículo desportivo a todos os títulos digno de espanto, o que lhe facilitava a vida nos meandros do mundo do desporto e do Olimpismo. Nestes ambientes, um campeão há-de ser sempre um campeão. Exeter, tinha participado em três Jogos Olímpicos: Paris (1924); Amesterdão (1928) e; Los Angeles (1932). Foi Campeão Olímpico nos 400 metros barreiras nos Jogos de Amesterdão (1928). Mais tarde, durante 40 anos exerceu as funções de Presidente da Amateur Athletic Association e de Presidente a IAAF durante 30 anos. Foi ainda membro do COI durante 48 anos. Portanto, um peso pesado do Movimento Olímpico, cuja opinião não podia deixar de se ouvir.

Exeter defendia que deviam ser criadas as condições para que a RPC regressasse ao movimento Olímpico. Para ele, o verdadeiro representante dos chineses era a RPC, na medida em que a China Nacionalista representava apenas uma pequena minoria. Exeter ia mesmo ao ponto de defender que o CON-Taiwan com sede em Taipé que se identificava com o seu nome original, Comité Olímpico Nacional Chinês, devia retirar a palavra China do seu nome. Contudo esta posição de Exeter que acabou por envolver
Brundage, não satisfazia os desejos da RPC na medida em que aceitava a continuação de um CON de Taiwan, quando o que a RPC desejava era a pura e simples exclusão de Taiwan do COI.

Independentemente de Exeter estar certo ou errado, o que é facto é que o COI ao entrar nesta dinâmica de pensamento ia contra tudo aquilo que o seu dirigente Avery Brundage tinha andado a dizer, isto é, que o desporto nada tinha a ver com a política. Em simultâneo, era entrar por um caminho muito complicado, na medida em que a ONU reconhecia a China Nacionalista - Taiwan como República da China. Quer dizer, o COI sobrepunha-se e antecipava-se à ONU, em defesa das posições da RPC. No entanto, o COI ao jogar desta maneira antecipava-se a um futuro mais que previsível. Contudo o que aconteceu, acabou por provar que, afinal, não chega ter razão, é necessário ter razão no momento exacto e no local apropriado. A Sessão de Munique não foi certamente nem o momento exacto nem o local apropriado.

\section{Diplomacia do ping-pong}

No início da década de 1970, perante um país com a economia em completo colapso e sob a ameaça da União Soviética, Mao Zedong iniciou uma manobra estratégica a fim de se aproximar dos EUA, muito embora o imperialismo americano fosse visto pelas autoridades de Pequim como o inimigo mais perigoso. O problema é que a nomenclatura chinesa começou a perceber que ainda havia um inimigo mais perigoso do que o mais perigoso dos inimigos. Esse inimigo era a URSS com quem a China para além de dividir a liderança de uma ideologia, partilhava ainda milhares de quilómetros de fronteira. O conflito latente entre a URSS e a RPC ultrapassava as próprias fronteiras da ideologia na medida em que tinha as suas origens nos tempos dos czares russos. Com a aproximação aos EUA o Presidente Mao Zedong, em primeiro lugar, afastou-se dos conflitos latentes com a União Soviética. Zhou Enlai dizia mesmo que as questões com a URSS estavam para além da possibilidade de serem geridas à margem do conflito. E compreende-se na medida em que a URSS tinha 43 divisões estacionada na fronteira com a RPC. Em segundo lugar, Mao demarcou-se da URSS que reivindicava a unificação do socialis- 
mo debaixo da tutela do Kremlin. Em terceiro lugar, conseguiu o reconhecimento internacional que a RPC não tinha conseguido enquanto aliada da URSS.

Desde a fundação da RPC em 1949, o mundo ocidental via o governo de Mao Zedong como ilegal, na medida em que, para a generalidade dos ocidentais, o verdadeiro governo da China estava refugiado em Taiwan. Com a aproximação aos EUA, os países ocidentais passaram a ver Mao Zedong como o legítimo regente da China continental.

Ao tempo, tanto a RPC como os EUA parece terem começado a perceber que as questões que os opunham jamais se resolveriam através de uma diplomacia de confronto, mas, pelo contrário, só podiam ter solução através de uma diplomacia de cooperação. Em conformidade, iniciaram um processo de negociações nos bastidores da política internacional. Se a RPC tinha interesse em abrir as suas relações ao Ocidente porque, para além da sua economia estar exausta queria fugir do jugo soviético, os EUA tinham interesse em afastar a RPC da influência soviética. Então, em 15 de Julho de 1971, o Presidente Nixon surpreendeu os americanos ao comunicar-lhes que, de 9 a 11 de Julho, tinha havido conversações em Pequim entre Zhou Enlai e Henry Kissinger e que o Primeiro-ministro Chinês o tinha convidado para visitar a China.

O mais significativo de todo este processo foi o facto das relações diplomáticas entre os EUA e a RPC, terem começado quando, a 6 de Abril de 1971, a equipa de ténis de mesa dos EUA que estava no Japão a participar no $31^{\circ}$ Campeonato do Mundo, recebeu um convite da RPC para visitar o país. A RPC estava pela primeira vez a participar no Campeonato do Mundo de Ténis de Mesa depois de, em 1958, ter decidido retirar-se de várias organizações desportivas internacionais. Entretanto, a 12 de Abril, nove jogadores americanos, quatro altos funcionários, acompanhados por 10 jornalistas, atravessaram uma ponte que liga Hong-Kong à China continental e, deste modo, inauguraram não só uma nova era nas relações internacionais, entre os EUA e a RPC, como também uma nova visão relativamente às funções que o desporto, no quadro da diplomacia internacional, pode assumir.

A partir de então, a "diplomacia do ping-pong" pas- sou contrariar o discurso de uma certa cultura inculta que afirma que o desporto nada tem a ver com a política. E o Primeiro-ministro Zhou Enlai durante o banquete em homenagem aos visitantes no Grande Hall do Povo em Pequim afirmou:

"Vocês abriram novo capitulo nas relações entre o povo americano e o chinês" (...) "Tenho a certeza de que o reinício de nossa amizade resultará num maior apoio entre os dois povos." $1 \mathrm{x}$

E a metáfora da "política de ping-pong" passou a fazer parte dos dicionários de ciência política. E, simultaneamente, um modelo de aculturação à escala global. E a prová-lo aí está o facto de quatro dos elementos da equipa Americana de ténis de mesa presentes nos Jogos de Pequim terem nascido na China.

\section{Entrada na ONU}

Por coincidência ou não, em Outubro de 1971 a Assembleia-geral das Nações Unidas, através da resolução 2758 (XXVI) de 25 de Outubro reconheceu a RPC, passando a considerar a província de Taiwan como uma das suas partes. Ora, este facto alterou completamente os dados do problema das "duas Chinas" na medida em que atribuiu à RPC uma situação muito mais confortável no quadro do seu prestígio no âmbito das nações. Desde logo porque a RPC começava finalmente a sair do isolamento a que tinha estado sujeita, desde a sua fundação em 1 de Outubro de 1949.

Depois, os Estados Unidos revogaram um embargo comercial contra a China e, em finais do ano de 1971, aproveitando a boa vontade gerada pela diplomacia do ping-pong, o Presidente Richard Nixon (1913-1994) anunciou que visitaria a China no ano seguinte, a fim de iniciar conversações formais entre os EUA e a RPC.

Um ano depois, uma equipa da RPC fez uma excursão pelos Estados Unidos. Sob o lema "amizade em primeiro lugar", jogou várias partidas com atletas americanos. Deste modo, a RPC iniciou uma nova era nas suas relações internacionais precisamente a partir da utilização do desporto enquanto instrumento do domínio da "diplomacia soft".

É evidente que o desporto pode e deve ser utilizado tal como qualquer outra actividade humana na promoção das relações entre os povos. Pode ser utilizado pelos governantes com boas ou más intenções. 
Todavia, não é por alguns líderes e organizações o utilizarem com objectivos que nada têm a ver com o interesse da generalidade das pessoas e dos países, que os dirigentes desportivos devam passar a fazer de avestruzes e a dizer que o desporto nada tem a ver com a política.

\section{Jogos Olímpicos de Montreal (1976)}

Uma vez dentro da ONU, a RPC acertou todas as suas baterias para conseguir entrar novamente no COI, aliás, de onde nunca devia ter saído. Assim, depois de, em 1972, ter conseguido, com o empenho directo de Zhou Enlai, o afastamento de Taiwan da Federação Asiática de Ténis de Mesa e da Federação dos Jogos Asiáticos, duas vitórias de significativa importância, a RPC virou-se decididamente para o movimento Olímpico. Em conformidade, começou a pedir a determinados membros do COI que manifestavam amizade e simpatia para com a RPC, para fazerem discursos a defender o regresso da RPC ao Movimento Olímpico. O que aconteceu foi que, em todas as sessões do COI e em diversas reuniões da Comissão Executiva do COI, o problema das "duas Chinas" esteve sempre presente.

Segundo Dongguang Pei (2006), ,xi cerca de seis meses depois da organização dos Jogos Olímpicos ter sido atribuída a Montreal o que aconteceu em 1970, o Canadá estabeleceu relações diplomáticas com a RPC. Claro que a RPC aproveitou a circunstância para fazer mais uma das suas jogadas estratégicas no sentido de acabar com a situação das "duas Chinas". A ideia que esteve quase a resultar, era conseguir da parte dos canadianos um convite directo para participar nos Jogos, impondo ao mesmo tempo a exclusão de Taiwan. Pelo seu lado, o Canadá para além de aceitar a entrada directa da RPC o que contrariava os compromissos assumidos com o COI, só permitiria a participação de Taiwan sob o nome de Taiwan como tinha acontecido em 1960 nos Jogos de Roma em que, Taiwan desfilou na cerimónia de abertura com um cartaz que dizia "under protest". O Governo do Canadá só revelou a sua posição em Maio de 1976. Ora, o COI não ficou nada satisfeito com a situação em vias de acontecer, na medida em que, se por um lado, a RPC não podia participar porque não era membro do COI, por outro, Taiwan não podia ser impedida de participar porque era membro do COI. Perante esta situação o COI emitiu o seguinte comunicado:

"A posição do Canadá está em conflito com os princípios fundamentais do Olimpismo pelo que os Jogos nunca deviam ter sido atribuídos ao Canadá (...) se o Canadá não tivesse garantido que os atletas de todos os Comités Olímpicos Nacionais reconhecidos pelo COI poderiam participar." "xii O que é facto é que a 9 de Julho de 1976, portanto a escassos dias da abertura dos Jogos, por um lado, a comitiva da RPC preparava-se para participar e, por outro, não tinham sido facultados vistos de entrada à delegação de Taiwan, quer dizer, estava a ser utilizado o mesmo truque que serviu para afastar Taiwan da participação nos IV Jogos Asiáticos realizados na Indonésia em 1962.

As posições eram de tal maneira irredutíveis que o COI chegou a considerar a possibilidade de cancelar a realização dos Jogos, ou, simplesmente, retirar-lhes a designação de Jogos Olímpicos. Contudo, o COI cedeu. Foi decidido prosseguir com os Jogos sem Taiwan.

Entretanto, perante a cedência do COI, o Presidente do Comité Olímpico Americano, com o apoio do Presidente Gerald Ford, ameaçou retirar dos Jogos a equipa dos EUA o que seria um desastre já que todos os contratos com as televisões americanas ficavam sem efeito. Claro que, perante tal ameaça, tinha de ser encontrada uma solução que satisfizesse, por um lado, a política de uma única China à qual o Canadá tinha aderido e, por outro, os princípios do COI que obrigavam à aceitação de Taiwan enquanto membro de pleno direito. Então, por envolvimento directo do Presidente do COI Lorde Killanine e do Primeiro-ministro Canadiano Pierre Trudeau, foi tentada uma solução em que Taiwan poderia competir debaixo da designação de Comité Olímpico de Taiwan. O problema foi que tanto Taiwan, como a RPC recusaram a proposta. Os Jogos acabaram por ter a sua abertura como estava previsto a 17 de Julho sem qualquer participação chinesa, o que, no fundo, significou uma derrota para todas as partes.

\section{Gato de Deng Xiaoping}

O ano de 1976 foi um ano em que se abriram, de facto, possibilidades para que o problema das "duas Chinas" pudesse de uma vez por todas ser resolvido. $\mathrm{O}$ que aconteceu de significativo foi que: 
- Zhou Enlai morreu a 8 de Janeiro;

- Mao Zedong morreu a 9 de Setembro;

— Em 6 de Outubro foi desencadeado um golpe de estado liderado por, entre outros, Deng Xiaoping;

- O Bando dos Quatro foi preso.

Em conformidade, Deng Xiaoping acedeu ao poder, dando-se por terminada a era de Mao Zedong e, simultaneamente, do tenebroso período da

Revolução Cultural. Entretanto, começaram as reformas de que a China há muito necessitava. Reformas sobretudo de mentalidades que vieram possibilitar a criação de novas oportunidades que permitiram o regresso da RPC ao Movimento Olímpico.

Pelo seu lado, para o COI era absolutamente necessário resolver a questão das "duas Chinas". A situação tinha atingido um padrão de conflito impossível de gerir, sem provocar estragos no próprio Movimento Olímpico. O que tinha acontecido nos Jogos de Montreal, não podia voltar a acontecer. Em conformidade, era necessário resolver a questão das "duas Chinas" antes dos Jogos Olímpicos de Moscovo (1980). O problema é que a questão estava bloqueada a menos que houvesse alguma flexibilidade de uma das partes interessadas. Mas qual delas estava em melhores condições de dar o primeiro passo? O COI, não podia ceder, expulsando pura e simplesmente o Comité Olímpico da República da China (Taiwan), na medida em que, ao fazê-lo, estava a tirar a milhões de jovens a possibilidade potencial de participarem nos Jogos Olímpicos. Pelo seu lado, a parte mais fraca de todo o processo que era Taiwan também não podia ceder na medida em que o tempo já não jogava a seu favor, pelo que os dirigentes sentiam o tapete a fugir-lhe debaixo dos pés. Assim, só restava a terceira parte do problema, quer dizer, a RPC. Na realidade, a RPC, das três entidades envolvidas, era aquela que tinha na mão a solução do problema, na medida em que era a única que, para começar, podia ceder qualquer coisa, desde logo porque tinha acabado de conseguir uma vitória muito significativa ao ser admitida no seio da ONU, para além de ter ficado livre dos líderes Mao Zedon e Zhou Enlai que, ao cabo de vinte anos de discussões e disputas inúteis, eram as principais dificuldades à resolução da questão. De facto, ao tempo de Mao Zedon e Zhou Enlai, a questão das "duas Chinas" era praticamente insolúvel na medida em que os líderes da RPC tinham radicalizado a sua posição de tal maneira que, dificilmente, podiam de lá sair sem perderem a face.

Com Deng Xiaoping a situação tornou-se radicalmente diferente. A Deng, como ele próprio dizia, não lhe interessava saber se o gato era preto ou branco desde que ele fosse capaz de caçar o rato.lxiii Quer dizer, não lhe interessava se o regime era capitalista ou comunista, desde que funcionasse. Portanto, a partir de então, as questões ideológicas deixaram de ter a importância do passado, tendo sido substituídas por um pragmatismo absolutamente necessário ao desenvolvimento económico da RPC e este desenvolvimento passava, também, pelo mundo do desporto, concretamente pela ambição que os dirigentes chineses há muito acalentavam de organizar os Jogos Olímpicos.

Nestes termos, estavam conseguidas as condições mínimas para se poder novamente voltar a equacionar o regresso da RPC ao Movimento Olímpico.

\section{Regresso à família olímpica}

De 14 a 19 de Setembro de 1977, o Presidente do COI Lord Killanin deslocou-se a Pequim a fim de se encontrar com membros da FAATC e com o Ministro da Cultura Física e do Desporto. Esta visita calhou num momento em que depois da morte de Mao Zedong, Deng Xiaoping ainda não tinha assumido verdadeiramente o poder. Segundo Xu Guoqi, ${ }^{30}$ o Presidente do COI passou em Pequim um tempo bem aborrecido, a ser doutrinado sobre o desporto na RPC e a questão de Taiwan. Entretanto, na $80^{\mathrm{a}}$ Sessão realizada de 16 a 20 de Maio em Atenas, relativamente ao assunto das "duas Chinas", Killanine informou que a RPC continuava a manter a sua posição de só voltar ao Movimento Olímpico depois da expulsão de Taiwan.

Um ano depois, também visitou Taiwan. Depois, na reunião da Comissão Executiva realizada em 25 e 26 de Janeiro de 1978 na Tunísia, Killanin relatou que a RPC exigia a expulsão de Taiwan como pré-condição para regressar ao COI. Pelo seu lado, o COI também não podia admitir essa solução drástica na medida em que era afastar um dos seus membros que, para todos os efeitos, exercia uma gestão efectiva sobre um território com milhões de cidadãos. Assim, a generalidade das opiniões ia no sentido de solicitar 
ao CON de Taiwan que mudasse o seu nome. António Samaranch foi membro do COI desde 1966 e foi Vice-presidente de 1974 a 1978. Nesta qualidade, também começou a aparecer no processo das "duas Chinas". Aliás, ele reivindica para si os louros de ter resolvido a questão das "duas Chinas". lxiv $\mathrm{Na}$ $81^{\text {a }}$ Sessão do COI realizada de 4 a 7 de Abril em Montevideu, Samaranch teve a oportunidade de esclarecer a sua posição dizendo que era fundamental para o Movimento Olímpico que a questão das "duas Chinas" fosse resolvida, uma vez que a ONU já tinha reconhecido a RPC e diversas Federações Internacionais já a tinham incluído entre os seus membros. A sua estratégia era clara: o COI convidava Taiwan a mudar de nome, como se sabia que Taiwan não mudaria, o COI votava a sua expulsão ou suspensão e estava o problema resolvido. (Liang, Lijuan, 2007:150). ${ }^{32}$ Claro que tal solução colocava o problema das "duas Chinas" no centro da política e pelas piores razões, na medida em que o COI entrava numa dinâmica em que os fins justificavam os meios. A solução ia, também, contra tudo aquilo que o COI defendia no que diz respeito a todos os chineses terem a possibilidade potencial de participarem nos Jogos. Ora, se Taiwan fosse expulsa do COI, a juventude de Taiwan deixaria de ter a possibilidade de participar nos Jogos Olímpicos.

Não era necessária uma medida tão drástica. Ao tempo, se por um lado a RPC se estava a tornar mais flexível, pelo que as autoridades já não defendiam com tanta convicção a expulsão do CON de Taiwan como condição para a sua entrada no Movimento Olímpico, por outro lado, o COI com Killanin, em final de mandato, estava a atingir um ponto em que a questão das "duas Chinas" se tinha tornado um assunto de primordial importância. Assim, o problema encaminhava-se para a sua resolução:

— Em 1978, a IAAF decidiu readmitir a Federação de Atletismo da RPC, muito embora a Federação de Atletismo de Taiwan, como não estava de acordo em ser expulsa, tenha movido uma acção contra a IAAF num tribunal de Inglaterra. A RPC tinha como objectivo recuperar rapidamente os lugares que tinha abandonado nas Federações Internacionais; — Em 1 de Janeiro de 1979, os EUA e a RPC reconheceram-se reciprocamente e estabeleceram relações diplomáticas formais entre si, para além de terem acordado entre si que Taiwan fazia parte da China; — Em Fevereiro de 1979 as autoridades da RPC deixaram de se referir às autoridades de Taiwan com a "clique de Chiang" e passaram a tratá-las como "autoridades de Taiwan". Ora, isto era uma mudança de atitude absolutamente fundamental para a resolução do problema; (Liang, Lijuan, 2007:157-158).32 - O COI envolveu alguns membros da Comissão Executiva em visitas à RPC e a Taiwan, a fim de melhor se identificarem com a questão;

- A própria revisão da Carta Olímpica (1978), instituiu uma nova perspectiva relativamente à palavra país. País passou a ser entendido como qualquer país, Estado, território ou parte de território.

Depois, a partir do estabelecimento de relações entre os EUA e a RPC, as mais diversas entidades e organizações começaram a pressionar para que o problema das "duas Chinas" fosse resolvido o mais depressa possível.

Ainda na $81^{\text {a }}$ Sessão do COI, He Zhenliang em representação do RPC abriu uma oportunidade para a resolução do problema ao colocá-lo nos seguintes termos: "De acordo com a Carta Olímpica somente um Comité Olímpico Chinês deve ser reconhecido. No respeito do direito de oportunidade dos atletas de Taiwan participarem nos Jogos Olímpicos o desporto em Taiwan pode passar a funcionar como uma organização local chinesa e continuar ligada ao Movimento Olímpico, sob o nome de Comité Olímpico Chinês de Taipé. Contudo, o seu hino, bandeira e estatuto devem mudar." (Pei, Dongguang:27)78

Estava finalmente dado o primeiro grande passo para que uma solução pudesse ser encontrada. De facto, a RPC alterou a sua posição, passando, em determinadas condições, a aceitar a coexistência com Taiwan. De acordo com Dongguang Pei78 esta foi, também, a primeira vez que as autoridades chinesas mostraram alguma abertura para CON de Taiwan incluir a palavra China no seu nome.

Assim, o COI, sob a presidência de Killanin, acabou por concluir um processo moroso e complicado mas, acerca do qual não estava isento de culpas. Em 25 de Outubro de 1979, numa reunião da Comissão Executiva do COI realizada em Nagóia no Japão, a RPC aderiu novamente ao COI. O CON da RPC ficou reconhecida no COI como Comité Olímpico Chinês (COC), enquanto que o Comité Olímpico de Taiwan passou a ser designado por Comité Olímpico 
Chinês de Taipé. Quer dizer, foi encontrada a solução que há muito podia ter sido encontrada.

\section{Regresso à competição séria}

O regresso ao Movimento Olímpico obrigou a RPC a alterar completamente a sua ideologia em matéria de desporto. Já não se tratava somente de ver a bandeira chinesa desfraldada na Aldeia Olímpica entre as demais bandeiras nacionais, como referia Liang Lijuan (2007) ${ }^{36}$ relativamente aos Jogos de Helsínquia (1952). O problema, passou a ser o da obtenção de resultados desportivos capazes de demonstrar que a RPC já não era mais aquele país agrícola, pobre e atrasado que a Revolução Cultural passou para o mundo.

Na realidade, o desporto na RPC deixou de ter qualquer relação com aquilo que se passava ao tempo da Revolução Cultural em que os ideólogos do regime, na linha do que se tinha passado na URSS vinte anos antes, ensaiaram construir um desporto não competitivo, absolutamente subordinado aos ditames dos interesses do Partido. Agora, segundo Liu Hong Bin, director da escola de desporto Shi Cha Hai:

"O treino é deliberadamente duro a fim de melhor fortalecer as crianças."

E acrescentou:

"Existe um provérbio chinês que diz que se encontra felicidade no sofrimento. As crianças podem encontrar felicidade no treino duro." $\mathrm{xv}$

Hoje, a RPC ultrapassou a anacrónica visão de um desporto não competitivo dos tempos da Revolução Cultural. O embaraço é que, em nome do Olimpismo ao serviço da economia, está a cair no extremo oposto. Muito provavelmente, a voltar aos valores preconizados por Mao Zedon quando em 1917 escreveu o livro "Um Estudo de Educação Física", aonde preconizava que "o principal desígnio da educação física era o heroísmo militar." Por isso, a situação hoje na China é preocupante. Ainda segundo Liu Hong Bin:

"Alguns pais, dizem aos nossos treinadores que podem bater nos seus filhos: se a criança não se comportar bem, por favor, bata nela"lxvi

A grandiosidade dos Jogos de Pequim, em nome do Olimpismo, ficará marcada por diversos estigmas sociais, desde os anacrónicos sistemas de ensino e de treino relatados no filme de Chao Gan "The Red
Race", lxvii até à deslocação de populações sem quaisquer compensações, passando pelos obscenos gastos em instalações desportivas.

O Movimento Olímpico e os seus dirigentes não podem olhar para esta situação dizendo que o desporto nada tem a ver com a política sob pena de negarem os princípios e os valores do próprio Olimpismo que, em quaisquer circunstâncias, deve estar ao serviço do desenvolvimento humano e da celebração da humanidade.

Este é o grande estigma que marcará para sempre o Movimento Olímpico, a menos que os Jogos de Pequim acabem por ser, como temos esperança que o venham a ser, o catalisador das mudanças necessárias e urgentes de que a Grande China e o desporto necessitam. Por mais que alguns dirigentes desportivos insistam que o desporto nada tem a ver com a política.

\section{A China e os Jogos Olímpicos}

A organização dos Jogos Olímpicos de Pequim era um sonho chinês com cem anos de idade. Como refere Susan Brownell (2007)23 o desejo dos chineses organizarem os Jogos Olímpicos era tão velho quanto a história do Olimpismo moderno. Em 1907, a YMCA desenvolveu um programa de educação física que começava por colocar três questões fundamentais: — Quando é que a China será capaz de enviar atletas vencedores aos Jogos Olímpicos?

- Quando é que a China será capaz de enviar equipas vencedoras aos Jogos Olímpicos?

- Quando é que a China será capaz de organizar os Jogos Olímpicos convidando o mundo para se deslocar a Pequim para neles participar?

A China enviou pela primeira vez atletas aos Jogos de Los Angeles em 1932. A RPC mandou pela primeira vez atletas ganhadores aos Jogos Olímpicos em Los Angeles (1984) - Jogos da Olimpíada. Finalmente, a RPC organizou os seus primeiros Jogos Olímpicos em Pequim em Agosto de 2008. Nesta conformidade, a China levou cem anos a cumprir o seu sonho olímpico.

Quanto à organização dos Jogos, a RPC apresentou a primeira candidatura em 1993 quando se propôs sediar os Jogos da XXVII Olimpíada. Acabou por ser prejudicada devido fundamentalmente aos trágicos acontecimentos da Praça Tiananmen em 1989. 
Depois, acabou por vencer a candidatura à organização dos Jogos da XXIX Olimpíada, tendo o Governo chinês prometido uma abertura do regime, uma maior liberdade de imprensa e um maior respeito pelos Direitos Humanos.

\section{Conclusão}

A diplomacia do ping-pong, desencadeada por Mao Zedong, foi o primeiro passo estratégico que conduziu a RPC de volta ao Movimento Olímpico internacional. Todavia, Mao não o fez pela causa desportiva. Fê-lo porque, ao tempo, interessava-lhe aproximarse dos EUA a fim de se libertar da URSS. Depois, com a morte de Zhou Enlai e Mao Zedong a Revolução Cultural atingiu o seu término. Com Deng Xiaoping ser rico passou a ser glorioso, pelo que a RPC abriu as portas ao capitalismo e, em consequência, a um desporto diferente do modelo não competitivo da Revolução Cultural. A um desporto que conduziu a RPC ao grande êxito que foi a organização dos Jogos de Pequim.

\section{CONCLUSÕES}

Muito embora Jiang Yu, a porta-voz do Ministério dos Negócios Estrangeiros da RPC tenha pedido a Jacques Rogge para manter o desporto afastado da política, o que é facto é que podemos concluir que desde sempre o RPC utilizou o desporto como instrumento da sua política. Os Jogos Olímpicos de Pequim, se do ponto de vista externo foram um poderoso instrumento de afirmação da China no mundo, o que lhe permitiu justamente assumir a sua velha força cultural e económica anterior ao século XIX, do ponto de vista interno, foram uma oportunidade para as autoridades promoverem, à custa do desporto e da representação nacional, um certo nacionalismo com o objectivo de manter o país unido.

Contudo, as autoridades chinesas sabem que uma moeda tem duas faces. Se do ponto de vista externo a afirmação da China no mundo está a ser um foco de preocupações de muitos países ocidentais que vêem as suas economias ameaçadas pelos baixos salários e regime de segurança social praticados, do ponto de vista interno, o tipo de mobilização nacionalista em curso, pode fazer percutir o tiro pela culatra. Aquando das manifestações de Londres e de Paris, a pretexto da passagem da Tocha Olímpica, se começaram a organizar contra manifestações espontâneas de cidadãos chineses no estrangeiro em defesa das posições da RPC, as autoridades de Pequim apressaram-se a desmobilizar as referidas manifestações com receio de que as mesmas fossem longe demais e pudessem contagiar o interior da própria RPC. Na realidade, acções deste tipo, como explica Eric Hoffer (1989) lxviii, têm o condão de, de um momento para o outro, sem que se perceba muito bem porquê, "virarem o feitiço contra o feiticeiro". Muitos dirigentes desportivos, apesar de todas as evidências, hão-de continuar a afirmar que o desporto nada tem a ver com a política. Hoje, é possível compreender que tal afirmação não tem qualquer significado. Nas palavras de Georges Magnane (1964), ,xix o desporto em si não é progressivo nem regressivo, como todos os factos sociais é uma criação perpétua dos homens que o praticam e organizam. Em conformidade, os homens são, por sua vez, transformados pelo próprio desporto e também o transformam. É nesta perspectiva, que entendemos que o desporto, para além de ser uma questão ideológica, muito embora os políticos não lhe prestem atenção até ao momento em que surgem problemas, ele próprio, pelas atitudes políticas a que obriga os governantes a assumir, é um agente provocador de ideologia. Quer dizer, as opções em matéria de desporto podem e devem ser objecto de confronto ideológico, sob pena do desporto em termos sociais não servir a não ser para alienar as massas ao serviço do poder vigente, seja ele qual for.

De toda a questão das "duas Chinas" é possível tirar algumas lições para o futuro. Foram demasiados os erros cometidos por todas as partes envolvidas, ao longo de mais de vinte anos, erros esses que se traduziram em desilusões e sofrimento para muita gente. - A aceitação por parte do COI da mudança de residência do Comité Olímpico Nacional Chinês para Taipé após 1949;

- A aceitação por parte do COI da participação da RPC nos Jogos de Helsínquia, quando ainda não existia um CON no país;

- A arrogância da RPC impondo ao COI os seus quadros políticos, ignorando que o Prof. Shou Yi Tng membro do COI ficara a viver na RPC, pelo que poderia ter tirado partido dele de uma forma positiva em vez de o massacrar em disputas com Avery Brundage; 
- As autoridades de Taiwan também não souberam utilizar os dois membros chineses do COI que tinham aderido à China Nacionalista;

- Tanto a RPC como Taiwan ignoraram que os membros do COI eram representantes do COI na China e não representantes da China no COI; - A ignorância total da RPC em matéria da organização Olímpica, tentando impor as suas decisões com violência e nenhuma elegância, a partir dos representantes políticos;

- A arrogância de Avery Brundage que sempre teve um comportamento favorável à China Nacionalista em prejuízo da RPC.

Com o boicote a Moscovo (1980), por paradoxal que possa parecer, a RPC acabou por só voltar a participar nos Jogos de Inverno Lake Placid (1980), e, depois, nos Jogos da XXIII Olimpíada em Los Angeles (1984), aos quais compareceu com 353 elementos dos quais 224 atletas. A RPC ficou em quarto lugar com 15 medalhas de ouro num total de 32 . Entretanto, a cooperação entre a China e o COI parece ter entrado num novo período. Em 1981, He Zhenliang, que em 1952 com 22 anos de idade, ao serviço do Partido, tinha ido a Helsínquia fazer de "intérprete" ao Prof. Shou He Tung, foi eleito membro do COI. Em 1985 foi eleito membro Comité Executivo e em 1989, vice-Presidente COI. Depois foi o grande responsável pelas duas candidaturas de Pequim ao Jogos Olímpico.

Como dos heróis não reza a história, para nós, o grande herói de todo este processo, foi sem sombra de dúvida o Prof. Shou Yi Tung que foi sacrificado por uma causa inútil sem que, pelo menos aparentemente, as autoridades chinesas o tenham reconhecido. Infelizmente, o Prof. Shou Yi Tung morreu em 1978 aos 83 anos, um ano antes de poder ver a China reentrar no Movimento Olímpico.

Hoje, o problema das "duas Chinas" continua por resolver, contudo, agora, existe uma "química harmoniosa" entre Pequim e Taipé. O Olimpismo, como muito provavelmente dirá Jacques Rogge, foi o catalizador para que aquela "reacção química" harmoniosa fosse possível.

Como afirmou Melo de Carvalho (2000), 1xx a crise do Olimpismo encontra-se encerrada em duas questões fundamentais. Por um lado, uma comercialização sem fronteiras, por outro, um falso discurso que procura escamotear a realidade da situação. E continuou dizendo que enquanto a estrutura do Movimento Olímpico é cada vez mais poderosa, o Ideal Olímpico tem vindo a caminhar progressivamente para a sua fragilização. E, dizemos nós, quando os princípios e os valores deixam de comandar o desporto, este transforma-se numa actividade de alienação de massas à margem do desenvolvimento humano.

Contudo, o mundo está a mudar a uma velocidade muito maior do que aquela que a generalidade das pessoas é capaz de se aperceber. As condições em que hoje o COI opera, são bem diferentes daquelas em que funcionava há oito ou dez anos. O que aconteceu de radical foi que, entretanto, a internet tomou conta do mundo e estabeleceu uma rede de relações virtuais entre milhões de pessoas, absolutamente inimaginável ainda há meia dúzia de anos. Ora, este facto está a transformar a maneira como o sistema desportivo mundial funciona. Hoje, estão a surgir diversas comunidades interessadas no fenómeno desportivo que interagem na rede, como ainda há meia dúzia de anos não era possível. Pelo seu lado, o COI está presente na internet com um "site" que fornece informação em tempo real acerca daquilo que está a acontecer no Movimento Olímpico aceitando deste modo expor-se de uma maneira absolutamente inimaginável ainda há meia dúzia de anos. A sociedade da comunicação em rede coloca as mais diversas organizações e os respectivos líderes debaixo dos olhares do mundo. Qualquer assunto, de um momento para o outro, pode assumir um "efeito de borboleta" e passar a estar nas bocas do mundo. Em consequência, o desporto está a funcionar cada vez mais a partir de redes de organizações que estabelecem entre si relações fluidas e mutáveis de interesses, com diferentes graus de formalidade. Nesta conformidade, deixa de fazer qualquer sentido que algumas organizações reivindiquem para si o vértice da pirâmide. Na realidade, a pirâmide já não existe. Haverá eventualmente muitas pirâmides em interacção. Quando muito, as redes funcionam em torno de uma multinacional, na base de alianças e cooperação. Está claro que num mundo em rede, a pirâmide organizacional da civilização industrial está a deixar de ter o sentido e a importância de outrora. Assim, o sistema desportivo mundial começa a funcionar com 
uma descentralização extrema e um alto padrão de flexibilidade que permitem um ajustamento em tempo real às novas realidades e provocações que, a todo o momento e de todos os lados, surgem. O sistema transcende fronteiras, identidades e interesses corporativos ou nacionais. Hoje, a FIFA e a UEFA, com frequência, pretendem intervir nos Estados nacionais. Por sua vez, redes de Estados nacionais, como é o caso da União Europeia (EU), também fazem vingar as suas opiniões junto das organizações supranacionais. ${ }^{\mathrm{xxi}}$

Constata-se ainda que o sistema está a evoluir de organizações multinacionais para redes internacionais à medida que o processo de globalização se desenvolve. Em consequência, o COI está a deixar de ser uma organização transnacional de representação mítica, em que a sua imagem foi construída em benefício próprio a partir de uma ideia de Pierre de Coubertin e dos seus amigos, para passar a ser uma organização internacional a funcionar em redes mais ou menos formais, mas cada vez mais descentralizadas. Por isso, a democraticidade do seu funcionamento é uma questão que, mais dia, menos dia, saltará para a discussão na rede.

Note-se que, e este é um dos principais problemas do COI e do próprio Jacques Rogge, o ponto fraco deste tipo de redes reside na sua incapacidade para processar grandes transformações que exijam acordos alargados. Nestes termos, não vale a pena pensar em mudar muito de uma só vez, como o pretendem as ONGs que pressionam o COI para desencadear grandes mudanças, mas idealizar estratégias para mudar muitas vezes ao longo do tempo. Para que isto seja possível, a rede tem de viver uma cultura de mudança que lhe é dada fundamentalmente pelo seu grau de educação e este leva tempo a consolidar. Estamos a viver tempos de mudança que já não se compadecem com discursos fechados, corporativos e sem sentido global, na medida em que já nada têm a ver com o mundo e o desporto à escala em que vivemos. Até porque, como refere Manuel Castells (2000), lxxii a lógica da rede é mais poderosa do que a lógica dos poderes dentro da rede. Nesta perspectiva, só agora é que o COI começa a ter força para processar as mudanças há muito necessárias, na medida em que haverá sempre elementos da rede a fazerem todo o tipo de pressão sobre a própria rede. Porque o COI estava prisioneiro do próprio COI. Jacques Rogge veio alterar este status quo. Entenda-se que a pressão sobre o COI só pode ser portadora de futuro. Contudo, na dialéctica de confronto de ideias numa estrutura em rede, alguns dos seus membros serão sempre mais iguais dos que os outros. Não se deve estranhar tal situação. De uma maneira geral, as relações de interdependência tendem a ser assimétricas. Como refere Melo de Carvalho, o fosso entre os países ricos e os $3^{\circ}$ e $4^{\circ}$ Mundos, alarga-se produzindo injustiças globais à escala do Planeta. Todavia, a denúncia sistemática e permanente dessas injustiças passou a fazer parte da rede e o COI já não pode pretender viver à margem delas, quer dizer, noutro mundo. Nestes termos, a gestão da incerteza é de fundamental importância no perfil de capacidades e competências daqueles que pretendem interagir na rede. Mas, a única solução para gerir surpresas é resolver a montante os problemas que lhes dão origem. No entanto, também se sabe que a incerteza agrava-se tanto mais quanto a dinâmica das relações internacionais deixou de ser analisada em exclusivo a partir do Estado. Hoje, são múltiplas as ONGs que interagem no sistema exercendo sobre ele enormes pressões através de redes formais e informais de informação que, paradoxalmente, está a criar um novo padrão de desenvolvimento que há-de organizar a sociedade do conhecimento.

Nesta perspectiva, o desporto é assumido como um instrumento de desenvolvimento humano pelo que deve voltar a ser considerado como ao tempo de Coubertin, quer dizer, como uma ferramenta de "soft-diplomacia", ao serviço das relações internacionais. Sempre que tal acontece, podemos dizer que o desporto está integrado numa dinâmica do chamado "soft power" que, ao longo da história do século XX, aconteceu por diversas vezes e em várias circunstâncias, umas com êxito, outras sem qualquer êxito. Por exemplo, aconteceu com êxito em 1971 em plena Revolução Culturallxxiii com a abertura da China ao mundo através da política do ping-pong desencadeada por Mao Zedong. A política do ping-pong acabou por ser bem mais eficaz do que o chamado "hard power" e da diplomacia de confronto de forças entre os dois países. Aconteceu sem qualquer êxito nos Jogos de Montreal (1976) quando vários países africanos protestaram contra o facto da equipa de râgue- 
bi da Nova Zelândia ter feito uma digressão pela África do Sul, furando o boicote desportivo em vigor. Os países africanos recusavam-se a participar nos Jogos a menos que a equipa da Nova Zelândia fosse afastada. O COI, em virtude do râguebi não ser uma modalidade olímpica, tentou ignorar a questão. Em consequência, a 48 horas do início dos Jogos, 30 países e cerca de 1000 atletas abandonaram Montreal. Entretanto, a atribuiu a realização dos Jogos da XXIX Olimpíada à cidade de Pequim, veio trazer uma nova dinâmica política e social ao Olimpismo moderno que tem vindo a estabelecer um corte com o "discurso de avestruz", quer dizer, a diplomacia do silêncio desencadeado nos anos cinquenta por Avery Brundage, com a máxima de que "o desporto nada tem a ver com a política". Hoje, este tipo de discurso, embora muitos dirigentes, como vimos anteriormente, ainda o queiram manter, está condenado ao fracasso na medida em que as estruturas de autoridade em linha estão cada vez mais desajustadas à dinâmica informacional/global e, como a questão das "duas Chinas" demonstra cabalmente, está, sempre esteve completamente desfasado da realidade. $\mathrm{O}$ mundo das organizações desportivas, deste modo, tem de se adaptar a um novo modelo organizacional a funcionar em rede, em alternativa ao modelo neoclássico de forma piramidal do passado.

Na perspectiva de Castells, a globalização e a informacionalização estão estruturalmente relacionadas com o funcionamento em rede e a flexibilidade. As organizações desportivas começaram a funcionar numa teia de redes múltiplas que fazem parte de uma grande diversidade de contextos institucionais. Perante este quadro, em que o poder muitas vezes é exercido de uma forma aleatória, o COI foi levado através de Jacques Rogge a protagonizar um discurso novo que, pelo menos aparentemente, começa a colocar novamente os valores da ideologia Olímpica no centro do desenvolvimento do Movimento Olímpico. Com este novo posicionamento, o COI: - Promove os seus próprios valores sem o cinismo do passado;

- Atrai a simpatia das pessoas e das organizações, através das suas atitudes claras;

- Torna-se uma instituição geradora de desenvolvimento e progresso aos olhos da comunidade mundial.
O mundo está a viver a uma velocidade vertiginosa, a viver um tempo complexo, de enorme precariedade associado a grandes transformações. Contudo, a velocidade imprimida à vida pela civilização pósndustrial dificulta à generalidade das pessoas a tarefa de compreender o tempo em que vivem. Apesar de tudo as coisas estão a mudar. Quando Jiang Yu, porta-voz do Ministério dos Negócios Estrangeiros chinês, pediu aos membros do COI para respeitarem o espírito da Carta Olímpica, ela sabia certamente do que estava a falar. Claro que, Jacques Rogge, também sabia do que falava, quando pediu à RPC para respeitar os compromissos assumidos quanto ao exercício dos direitos humanos na China.

\section{NOTAS}

I Olimpíada: Segundo a Regra Seis no 2 da Carta Olímpica "os Jogos Olímpicos são os Jogos da Olimpíada e os Jogos Olímpicos de Inverno." Com a Carta Olímpica que entrou em vigor em 1 de Setembro de 2004 deixou de existir o conceito de Jogos Olímpicos de Verão que até então determinavam o período da Olimpíada. Agora, segundo o Texto de Aplicação à Regra Seis, "uma Olimpíada é um período de quatro anos civis consecutivos que começa no primeiro de Janeiro do primeiro ano e termina em 31 de Dezembro do quarto ano." As Olimpíadas contam-se a partir dos primeiros Jogos da Olimpíada celebradas em Atenas em 1896. "A XXIX Olimpíada começa em 1 de Janeiro de 2008. Os Jogos da XXIX Olimpíada serão realizados em Pequim. Deste modo, as Olimpíadas deixam de estar associadas exclusivamente aos Jogos Olímpicos que se realizam no Verão.

II A Matriz BCG (Boston Consulting Group) é um modelo utilizado para análise do ciclo de vida do produto. No ciclo da Vaca Leiteira, os lucros encontram-se no apogeu.

III Quando Pierre de Coubertin (1863-1837), em finais do século XIX, fundou o COI e institucionalizou os Jogos Olímpicos da era moderna não podia de maneira nenhuma fugir à realidade económica social e política do seu tempo. Coubertin era um pedagogo, sobre isto não existem quaisquer dúvidas, contudo, para ele, a pedagogia era um instrumento da política. Coubertin defendia que: "Para que ele (o desporto) se torne um adjuvante directo, é necessário que se lhe atribua um objectivo reflectido de solidariedade que o eleve acima dele mesmo." E este é um dos grandes equívocos dos seus detractores. Na realidade Coubertin entendia o desporto para além do próprio desporto, e foi nesta perspectiva que em 1894 se lançou àquilo a que ele próprio designou como "a conquista da Grécia". Ao tempo, o que estava em causa era a organização dos Jogos de Atenas em 1896, contudo, como podemos apreciar nas suas "Memórias Olímpicas", até ao último combate da sua vida que foi a defesa da realização dos Jogos de Berlim em 1936, nunca Coubertin deixou de utilizar o desporto como um instrumento político ao serviço do Olimpismo e do desenvolvimento humano. Pode ter errado mas, quando o fez, fê-lo com a convicção das suas ideias e à margem de muita hipocrisia que mais tarde veio a envolver as questões do Olimpismo e do próprio desporto.

IV Para fundamentar a sua expressão de que o desporto nada 
tinha a ver com a política, Brundage afirmava: "Se aceitamos que num mundo imperfeito como o nosso, se deixe de praticar desporto, cada vez que as leis humanas são violadas, nunca haverá competições internacionais." In: Brundage, Avery (1973). Memórias. Madrid, Instituto Nacional de Educación Física, p.260.

v A 7 de Agosto de 2007, precisamente um ano antes da cerimónia de abertura dos Jogos Olímpicos de Pequim, Jacques Rogge publicou um artigo de opinião no Herald Tribune aonde afirmava: " O Movimento Olímpico não existe no vácuo. O desporto faz parte da sociedade." E continuou: "É natural que organizações como as dos direitos humanos e outras coloquem as suas causas sob a luz que os Jogos olímpicos estão a colocar na China a fim de chamarem a atenção para as causas que advogam. Contudo, os Jogos só podem ser um catalizador de mudança e não uma panaceia."

vi A Amnistia Internacional tem exercido pressão sobre os mais diversos CONs por esse mundo fora. Teresa Nogueira, da secção portuguesa da Amnistia Internacional, criticou o facto de a sua organização não ter sido recebida pelo Comité Olímpico de Portugal. (In: TSF on line, 02/4/2008.

VII In: Lusa, 29/7/2008.

VIII Conferir: Pulido, Valente, Vasco (1988). A Feira dos

Horrores. In: “O Independente", 7 de Outubro de 1988.

Ix A este respeito ver "The Red Race", um filme de Chao Gan que mostra os exageros físicos e emocionais da alta competição. Mostra a tortura e a humilhação a que são submetidas crianças chinesas às mãos dos seus treinadores. Entra-se no domínio da exploração do trabalho infantil e do desrespeito pelos Direitos do Homem.

X A decisão sobre a cidade organizadora é realizada com sete anos de antecedência, depois de um processo longo e sofisticado que pode ser consultado no SITE do COI.

XI In: Newsweek, 6/10/2008. Entrevista de Zakaria Fareed ao Primeiro-Ministro Chinês Jiabao.

http://www.newsweek.com/id/161410/page/1

XII Vieira, Flávio, Vilela (2006). China: Crescimento Económico de Longo Prazo. In: "Revista de Economia Política”, vol.26 n.3, São Paulo Julho/Set. 2006.

XIII In: Textos aprovados pelo Parlamento - Edição provisória : 05/07/2001 - Candidatura de Pequim aos Jogos Olímpicos de 2008 - B5-0487, 0498, 0505 e 0524/2001. In:

www.europarl.europa.eu

XIV In: Público, 20/03/2008.

xv In: CRI - Rádio Internacional da China.

http://portuguese.cri.cn/183/2008/10/06/1s96779.htm

xvi Conferir: Pires, Gustavo \& Correia, José, Pinto (2006). Os

Jogos da Lusofonia na Geoestratégia da China. In: http://forumolimpico.org/?q=node $/ 275$

XVII Lusa em Macau, 09/10/2006.

http://esporte.uol.com.br/outros/ultimas /2006/10/09

XVIII In: http://www.sportmarketing.com.br/search?q=terracotta

xIx In: http://www.marxists.org/reference/archive/mao/selected-works/index.htm

xx Conferir: Morris, Andrew (2008) How Could Anyone

Respect Us?: A Century of Olympic Consciousness and National Anxiety in China. In: The Brown Journal of World Affairs, Vol. XIV, Issue II Sping/summer, 25-39. XxI Conferir: Spivak, Marcel (1987). A Política Desportiva da Frente Popular. Lisboa. Direcção-geral dos Desportos. Col Desporto e Sociedade.

XXII In: http://www.un.org/apps/news/
xxIII In: Público, 13/4/08.

xxiv Conferir: Brownell, Susan (2007). China and the Olympic Games: Body Culture, East and West. Amsterdam School for Social Science Research, Staffseminar on Body, Society, Politics. Xxv In: Olympic Review n. 64 November 1958, p. 42.

xxvi Conferir: Brundage, Avery (1973). Memórias. Madrid, Instituto Nacional de Educación Física. p 261.

xxvII Conferir: Guoqi, Xu (2008). Olympic Dreams - China and Sports - 1895-2008. USA: Harvard University Press.

xxVIII Conferir: Lennartz, Karl (1995). The Edström Presidency (1942-1952). In: The International Olympic Committee One Hundred Years - The Idea - The Presidents - The Achievements. Lausanne, International Olympic Committee, Vol. II.

xxIx In: Olympic Review, n³2, Mars 1952. (p.14). 46ª Sessão do COI, Oslo, 12-13 Fevereiro de 1952.

xxx In: Review Olympic, n. 66-67, Juin 1973, p.171.

xxxI In: Review Olympic, n. 66-67, Juin 1973, p.172. Não faz qualquer sentido colocar em termos idênticos as questões raciais religiosas e políticas. Têm conteúdos ideológicos diferentes e por isso devem ser tratadas de forma diferente. Desde logo separando as políticas que é uma categoria maior das outras, religião e raça, que serão sempre sub-categorias da política.

xxxII In: Review Olympic, n. 66-67, Juin 1973, p.172. Esta medida não teve qualquer efeito, tanto no momnto, como relativamente ao futuro.

xxxIII Conferir: Liang, Lijuan (2007). He Zhenliang and China's Olympic Dream, Pequim, Foreign Languages Press, Tradução: Susan, Brownell, (p.27). Liang Lijuan foi jornalista do "People's Daily. Participou nas duas candidaturas de Pequim à organização dos Jogos Olímpicos. Mas a informação mais importante, é a de que Liang Lijuan é casada com He Zhenliang o que confere uma credibilidade muito importante à narrativa acerca de toda a dinâmica do desenvolvimento do desporto na RPC a partir de 1949. Esta credibilidade é tanto mais de considerar quanto se percebe a ingenuidade com que determinados episódio são relatados, como, por exemplo, o da viciação de resultados ao tempo do Primeiro-ministro Szou Enlai.

xxxIv Conferir: Ron Gaotang (1912-2006), foi secretário-geral do Comité Nacional da Educação Física e Desporto. Foi o primeiro chinês a receber a medalha de prata da Ordem Olímpica que lhe foi atribuída pelo antigo Presidente do COI Juan Antonio Samaranch em 1983, pelos serviços prestados ao desenvolvimento do desporto chinês.

xxxv In: Review Olympic, n. 66-67, Juin 1973, p.171. xxxvi Conferir: Lennartz (1973:75) cf.: Liberg, W. (1989). The IOC Sessions1894-1955. Unpublished manuscript, (p. 289). IOC Archives.

XxxVII In: Olympic Review n. 64, November 1958, p.42. xxxvIII Conferir: Schantz, Otto (1995). The Brundage Presidency (1952-1972) In: The International Olympic Committee One Hundred Years - The Idea - The Presidents - The Achievements. Lausanne, International Olympic Committee, Vol. II xxxIX In: http://en.olympic.cn/

XL In: Olympic Review n. 64, November 1958, p.42.

xLi Pela Declaração do Cairo, assinada em Dezembro de 1943, os Estados Unidos, o Reino Unido e a China declararam que o Japão devia devolver o nordeste da China, Taiwan e arquipélago Penghu à China.

xuII Declaração de Potsdam - Conferência entre os países vitoriosos da II Guerra Mundial (Grã-Bretanha, União das Repúblicas Socialistas Soviéticas, EUA) ocorrida em Potsdam, Alemanha (perto de Berlim), entre 17 de Julho e 2 de Agosto de 1945 que, 
entre outros assuntos, ultimou os termos de capitulação incondicional do Japão. Tendo o Japão recusado foram lançadas bombas atómicas em Hiroshima e Nagasaki a 6 e 9 de Agosto de 1945. A Declaração de Porsdam diz concretamente: "The terms of the Cairo Declaration shall be carried out and Japanese sovereignty shall be limited to the islands of Honshu, Hokkaido, Kyushu, Shikoku and such minor islands as we determine." XLIII Conferir: Bouet, Michel (1968). Signification du Sport. Paris: Ed. Universitaires.

XLIV $\mathrm{O}$ que aconteceu foi que a RPC conseguiu manobrar nos bastidores de modo a que a República da China (Taiwan) não participasse nos $\operatorname{IV}^{\circ} \mathrm{s}$ Jogos Asiáticos porque os vistos de entrada na indonésia nunca lhes chegaram às mãos. (Conferir: Liang, Lijuan (2007). Ibidem, p.82-83. Em matéria de utilização do desporto pela política, a RPC nunca "brincou em serviço". Sempre colocou o desporto ao serviço da política. Só que o fez de uma forma clara e leal, enquanto que outros o fizeram de forma encoberta e muita hipocrisia.

XLV Conferir: Hoberman, John (1984). Sport and Political Ideology, USA: University of Texas Press.

XLVI In: http://www.napavalleyregister.com/articles/2005/10/30/business/ap/iq_3142979.txt XLVII Games of the New Emerging Forces (GANEFO). XLVIII A União das Repúblicas Socialistas Soviéticas também mandou atletas aos Jogos. Contudo para não comprometer a organização enviou atletas de segunda categoria. O desporto ao serviço da política. E bem.

XLIX É nesta perspectiva que vemos a realização dos Jogos da Lusofonia que tiveram a sua primeira edição em 2007 em Macau aonde se gastaram cerca de 7 milhões de euros num desperdício a todos os títulos condenável. Os Jogos da Lusofonia avançaram por interesse dos chineses que levaram a reboque o nosso atávico provincianismo que, no fundo, justifica o subdesenvolvimento relativo do país. Os segundos Jogos da Lusofonia estão previstos para serem realizados em Portugal no ano de 2009 a menos que alguém com um mínimo de bomsenso e sentido do interesse público seja capaz de os travar. L O problema é que a visão marxista que entendia a prática desportiva como uma actividade lúdica, não competitiva em que as modalidades individuais eram estigmatizadas em função do colectivo das modalidades de equipa, provocou não só devastadores efeitos na China como em diversos países da Europa. Por exemplo, em França, os ideólogos da designada "nova esquerda", cuja figura mais proeminente foi Jean-Marie Brohm, acompanhado por, entre outros, Genette Berthaud, François Gantheret e Pierre Laguillaumie, espalharam através do trabalho colectivo "Sport, Culture \& Répression" publicado na "Partisans", aquilo a que chamavam "uma crítica fundamental do desporto", que acabou por dar expressão a uma linha de pensamento que se traduziu numa prática desportiva pretensamente higiénica, ilusoriamente pedagógica e mediocremente competitiva, que acabou por ser expressa nos programas de "Educação Física", de diversos países entre os quais Portugal, com efeitos devastadores na organização do desporto não só no Sistema Educativo como no Desportivo.

LI In: Olympic Review, n 67 , August 1959, p.63.

LII Guerra-fria é a designação atribuída ao conflito político-ideológico entre os Estados Unidos (EUA), defensores do capitalismo, e a União Soviética (URSS), defensora do socialismo. Decorreu entre o final da Segunda Guerra Mundial (1945) e a extinção da União Soviética (1991). A guerra era designada de "fria" em virtude de não ter havido confronto entre as suas super potências.

LIII In: Olympic Review n. 68, November 1959, p.35.
LIV In: Olympic Review n. 67, August 1959, p.63.

LV In: Olympic Review n. 68, November 1959, p.35.

LVI In: Olympic Review n. 67, August 1959, p.88.

LVII In: Olympic Review n. 67, August 1959, p.88.

LVIII Conferir: Miller, David (1992). Revolution Olímpica -

Biografia Olímpica de Juan António Samaranch. Barcelona:

Ediciones Península, p.245. Henry Hsu foi eleito na $69^{a}$ Sessão do COI. Depois acabou por se revelar um elemento muito positivo na resolução do problema das "duas Chinas".

LIX In: Olympic Review, n 67, August 1959, p.75.

LX In: http://usinfo.state.gov/journals/itps/0406/ijpp/pingpong.htm

LXI Conferir: Pei, Dongguang (2006). A Question of Names: The Solution to the Two Chinas' Issue in Modern Olympic History: The Final Phase, 1971-1984. In: 8th Symposium International for Olympic research. http://www.la84foundation.org/SportsLibrary/ISOR/ISOR2006c.pdf

LXII Conferir: J. Saywell (1977). The Olympic Games: Canadian Annual Review of Politics and Public Affairs for 1976. Toronto, University of Toronto.

LXIII A Metáfora do "gato branco e do gato preto" é descrita em: Pei, Dongguang (2006). A Question of Names: The Solution to the Two Chinas' Issue in Modern Olympic History: The Final Phase, 1971-1984. In: 8th Symposium International for Olympic research.

http://www.la84foundation.org/SportsLibrary/ISOR/ISOR2006c.pdf), a partir de Deng Xiaoping o idealismo foi progressivamente substituído pelo realismo.

LXIV Conferir: Miller, David (1992). Revolution Olímpica Biografia Olímpica de Juan António Samaranch. Barcelona: Ediciones Península, p.176 fotos.

LXV In: http://news.bbc.co.uk/sport2/hi/tv_and_radio/grandstand/4467434.stm

LXVI In : http://news.bbc.co.uk/sport2/hi/tv and radio/grandstand/4467434.stm

LXVII In: http://www.youtube.com/watch?v=XYdetXI3uIs

Lxvill Conferir: Hoffer, Eric (1989). The True Believer -

Thoughts on the Nature of Mass Movements. New York: Harper \& Row.

LXIX Conferir: Magnane, George (1964). Sociologie du Sport. Paris: Galimard.

LXx Conferir: Carvalho, Melo de (2000). Hipocrisia ou Função Humanista? In: "Avante", no 1403, 19 de Outubro e no 1415 , 11 de Janeiro de 2001.

LXXI A lei Bosman do Tribunal de Justiça da União Europeia permitiu que os futebolistas enquanto trabalhadores comunitários, não se vissem impedidos de jogar noutro país da União Europeia por normas internas da UEFA e das respectivas Federações nacionais de Futebol.

LXXII Conferir: Castells, Manuel (2000) A sociedade em Rede A era da Informação: economia, sociedade e Cultura. Lisboa: Fundação Calouste Gulbenkian. Vol. I.

LXXIII A Revolução Cultural da China foi um movimento de massas na RPC ocorrido entre 1966 e 1976, desencadeado por estudantes e trabalhadores, contra a burocracia que tomava conta do Partido Comunista Chinês. Por exemplo, o grande obreiro das duas candidaturas da RPC à organização dos Jogos Olímpicos e actualmente membro do COI, He Zhenliang, foi apanhado pela "revolução cultural" tendo sido destacado pelo Partido para trabalhos na província. Em Novembro de 1969 Zhenliang foi enviado pelo Partido para "May 7 Cadre School" na província de Shanxi para reeducação onde ficou durante um ano e meio", Conferir: Liang, Lijuan (2007). Ibidem, p.90. 